\title{
A Design Science Research Methodology for Expert Systems Development
}

\author{
Shah Jahan Miah \\ College of Business, Victoria University \\ Footscray Park campus, Melbourne, Australia \\ shah.miah@vu.edu.au \\ Hussein Genemo \\ College of Engineering and Science, Victoria University \\ Footscray Park campus, Melbourne, Australia
}

\section{Abstract}

The knowledge of design science research (DSR) can have applications for improving expert systems (ES) development research. Although significant progress of utilising DSR has been observed in particular information systems design - such as decision support systems (DSS) studies - only rare attempts can be found in the ES design literature. Therefore, the aim of this study is to investigate the use of DSR for ES design. First, we explore the ES development literature to reveal the presence of DSR as a research methodology. For this, we select relevant literature criteria and apply a qualitative content analysis in order to generate themes inductively to match the DSR components. Second, utilising the findings of the comparison, we determine a new DSR approach for designing a specific ES that is guided by another result - the findings of a content analysis of examination scripts in Mathematics. The specific ES artefact for a case demonstration is designed for addressing the requirement of a 'wicked' problem in that the key purpose is to assist human assessors when evaluating multi-step question (MSQ) solutions. It is anticipated that the proposed design knowledge, in terms of both problem class and functions of ES artefacts, will help ES designers and researchers to address similar issues for designing information system solutions.

Keywords: Design Science Research; Expert Systems; Multi-step Question; Method Marking Concept; IS design

\section{Introduction}

Improvement of artefact design knowledge is one of the essential components of information systems (IS) design research (Hevner et al., 2004; Hevner, 2007). IS design that applies contemporary methodologies can provide new knowledge that could improve particular IS artefact designs. The knowledge of design science research (DSR) has been explored and utilised for particular IS design aspects; for example in decision support systems (DSS) design (Arnott \& Pervan, 2014). This implies that DSR methodologies can have an application in improving expert systems (ES) development research. One of the methods used to extend the application of DSR methodologies in ES development research requires the analysis of ES literature and its successful application, demonstrated in a relevant problem domain. The aim of the first part of the study was to conduct a qualitative content analysis to discover the application of DSR in existing ES design studies over the period 2005 to 2015. These findings were subsequently used to form new design knowledge for developing and evaluating a specific ES by implementing a problem domain-specific method (called the method marking concept - MMC) to assess algebraic questions with multi-parts in Mathematics. This provided a case demonstration, now reported in this paper.

ES is one of the rapidly-growing IS applications that require contemporary design methodologies. A good ES artefact design must make a clear contribution, not only to target problem solving and its practices, but also to produceinteresting methodological contributions to particular IS design theory (Miah, Kerr \&Gammack, 2009). Classical ES design approaches, such as traditional system development and prototyping, provide little support to ES 
developers for conveying the methodological contributions for ES design. Hull and Kay (1991) clearly articulated a requirement of comprehensive methodology for ES design. The requirement has also been reinforced in a relatively recent study by Mansiya et al. (2014) who recommended that methodology for the ES design must be able to build more than scientific innovation in order to solve problems. Mansiya et al. (2014) argued that the ES development methodology should be able to capture theoretical, technological and organisational development requirements as the ES is one of the few types of IS that are often developed on artificial intelligence, and that have a defined use for human beings and have a practicalspecific application. We therefore contend in this paper that an ES developer needs to employ approaches that are different from traditional methods because ES development includes knowledge-based activities that are significantly different from the traditional IS approach (Angeli, 2010) and, as a contemporary methodology, DSR can offer benefits when particular IS artefact innovations such as decision support systems are being designed (Arnott \& Pervan, 2014).

The purpose of the study was to reinforce the use of DSR for ES design by exploring its current status in the literature, and showcasing an ES design using DSR in a practical problem context. First, we explored the ES development literature to reveal the presence of DSR as a research methodology. For this we selected relevant literature criteria and applied a qualitative content analysis in order to generate themes inductively to match the DSR components. The findings are presented through the seven guidelines of DSR proposed by Hevner et al. (2004). Second, by utilising the findings of the comparison, we determined a new DSR approach for designing a specific ES that was guided by another result - that of a content analysis of exam scripts in Mathematics. The specific ES artefact was designed for addressing the requirement of a 'wicked'1 problem in that the key purpose was to assist human assessors when evaluating multi-step question (MSQ) solutions in Mathematics.

The paper is structured as follows. Following this introduction, Section 2 Study background introduces areas of the study including the practical problem domain. Subsequently, Section 3 Research approaches describes how the study is conducted, Section 4 ES Artefact Design provides the details of the ES artefact, Section 5 ES Artefact Evaluation includes the artefact evaluation details, and finally Section 6 Discussion and Conclusion summarises the key contributions and further directions in the study.

\section{Study Background}

\subsection{Expert systems}

An ES is a computer based IS that uses artificial intelligence (AI) technologies. Research in ESs is centred on finding the best ways to represent human skills, expertise and reasoning in the form of computer software that mimics human activities in solving problems (Mansiya et al., 2014). ESs play important roles in many fields: (1) as decision support and knowledge processing systems to aid medical practitioners in taking proper decisions (Boulos, 2012; Kaidar et al., 2013); (2) as advisors to educators (Hwang et al., 2011) and farmers (Khan et al., 2008); (3) in mathematics knowledge assessment, especially in tutoring (J aques et al., 2013); and (4) in diagnosing plant diseases (Khan et al., 2008). All types of ESs require knowledge to operate with their functionalities. There are three main categories of knowledge: declarative, procedural and meta-knowledge (Turban et al., 2005, p. 582). Declarative knowledge is identified as the type of knowledge that is based on facts and truth, and which is represented in the form of factual statements that someone can understand and rationalise (Anderson, 1988; Giarratano \&Riley, 2005; Stalnaker, 2012). Stalnaker (2012) argues that the differences

\footnotetext{
${ }^{1}$ Wicked problems are defined through five relevant characteristics: unstable requirements due to unclear environmental context; complex interactions between components of the problem and its solutions; inherent flexibility to change design processes; critical dependence upon human users' cognitive abilities; and critical dependence upon human users' social abilities (Hevner et al., 2004, p. 81)
} 
between procedural and declarative knowledge arise from the way they are used, and this difference has its roots in computer science. Declarative knowledge is required in all stages of the ES cycle; for example domain experts share facts using declarative knowledge during knowledge acquisition. On the other hand, procedural knowledge is knowledge that requires information about doing things (J aques et al., 2013).

Figure 1 shows three basic building blocks that constitute a functioning ES (Sasikumar et al., 2007, p. 14; Turban et al., 2005, p. 554-555). The larger box contains the knowledge base and inference engine, which are the kernel of a basic ES, while the smaller box holds a user interface through which human users interact. The knowledge base stores the domain knowledge that the inference engine utilises to accomplish requested tasks (Durkin, 1994, p. 28; Giarratano \& Riley, 2005, p. 6). Domain knowledge is extracted from experts who have expertisein a specific domain to solve the problem (Giarratano \& Riley, 2005, p. 7). The components of the knowledge base are (1) facts and theories of problems, and (2) special heuristics or rules that direct the use of knowledge to solve specific problems in a particular domain (Turban et al., 2005, p. 556). The task of the inference engine is to use the knowledge (of the knowledge base) to reach a conclusion - that is, perform tasks - through reasoning similar to that employed by humans (Turban et al., 2005, p. 556). There are also other components, such as a user interface, that are required to complete the functionality of an ES.

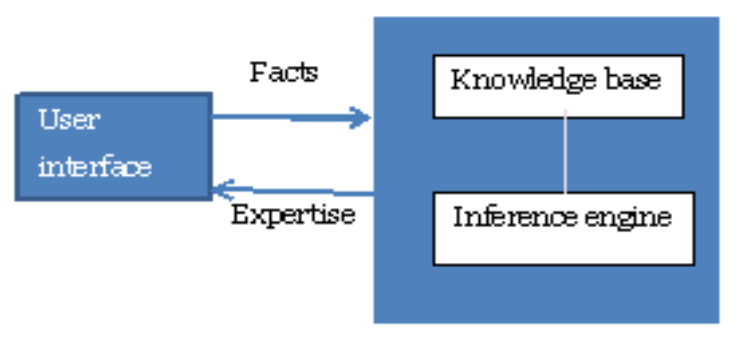

Figure 1: Basic Expert System Components

\subsection{ES design methodologies and design science research}

Traditional system development methodologies have been used as dominant methods for constructing ES. The methodologies are defined widely in order to capture broader aspects for guiding activities; this is due to the diversity of tasks and participants involved in developing IS artefacts. In this article we accept the definition of IS as "a system in which human participants and/or machines perform work (processes and activities) using information, technology, and other resources to produce informational products and/ or services for internal or external customers" (Alter, 2008, p. 6). Specialised IS includes various decision support systems (e.g. group decision support systems, negotiation support systems), knowledge based systems, executive information systems, management information systems, intelligent systems and ESs (Arnott \& Pervan, 2008; Power, 2010). These systems help to continuously improve ways of decision making as they provide appropriate information or knowledge support in order to perform tasks. An ES is a specialised IS that is aimed at solving complex problems in a particular domain, or to assist in making decisions in a particular domain by imitating human experts (Sasikumar et al., 2007; Giarratano \& Riley, 2005; Turban et al., 2005).

The traditional development methodologies encompass steps for identifying and analysing problems and system requirements, designing solution strategies, implementing system solutions and testing the system in the problem domain (Coussement et al., 2015; Shao et al., 2009; Haji et al., 2014). For instance, Haji et al. (2014) utilised a basic life-cycle methodology for designing an ES for educational purposes. Their methodology consisted of phases such as problem definitions, ES architecture design and implementation. Sanders et al. (2009) also used phases such as design, development and evaluation. These types of traditional 
methodologies are consisted with a starting phase of knowledge acquisition or problem identification (for example, see Andersen et al., 2013), then designing the ES artefact by, for example, designing different components (e.g. knowledge base, inference engine, and user interface) and finally with a phase of evaluation within the practical problem context (Wu et al., 2012). For the ES design, in many cases, these methodologies are supportive of the knowledge that needs to be acquired in meeting the particular demands of the ES design.

Beyond the capacity of the traditional IS methodologies, design science has gained momentum in IS research for designing contemporary solutions since Nunamaker, Chen and Purdin (1990) first introduced this paradigm as an effective design methodology. Hevner et al. (2004) described how the DSR is particularly relevant for modern-day IS research, because it helps IS researchers confront two of the major long-term issues within IS design: (1) the absence of rigour in designing innovative artefacts and (2) the nature of IS research outputs, many of which produce irrelevant knowledge that is not practically applicable to real-world problem solutions (Orlikowski \&Iacono, 2001; Benbasat \&Zmud, 1999). DSR is now generally accepted as a valid design methodology for many specialised IS designs (e.g. DSS development) as it contributes to knowledge and design theories beyond practical problem solving (Arnott \& Pervan, 2014; Gregor \&Hevner, 2013; Hevner \& Chatterjee, 2010). It implies that progression of DSR in the IS development field, in general, is significant; consequently, since ES is a subset of IS, a DSR methodology may also bring benefits for novel ES design.

DSR provides methodologies emanating from engineering and the artificial sciences (Simon, 1996). It "seeks to create innovations that define the ideas, practices, technical capabilities, and products through which the analysis, design, implementation, management, and use of information systems can be effectively and efficiently accomplished" (Hevner et al. 2004, p. 76). This implies that DSR is particularly relevant for innovative solution design such as an ES, because it may better support designers/ researchers in exploring its grounding knowledge (e.g. knowledge contribution) and embedding behavioural or human aspects into the artefact design. A major publication having an impact in IS research is the study by Hevner et al. (2004), in which seven DSR guidelines are offered to develop and evaluate IS artefacts. Since 2004, the seven guidelines have been used for innovative DSS development (Miah, Kerr and von-Helens, 2014), business modelling implementation (Ahmed \& Sundaram, 2012) and other types of IS design.

The design guidelines derived from knowledge and understanding of design problems by Hevner et al. (2004) are predominantly representative of DSR as it is inherently a problem solving process. According to Hevner et al. (2004) the first guideline provides support for the creation of a solution artefact, the second guideline is for specifying the problem domain while the third guideline is for evaluating the solution artefact. The fourth guideline is supportive of developing an innovative artefact to address new wicked problems or improve the solution of existing problems. The fifth guideline is to ensure that the artefact must be rigorously defined, formally represented and internally consistent with problems being addressed. The sixth guideline supports the need for a search process that will find an effective solution. Finally, the seventh guideline provides support for communicating the designed artefact to both technical and organisational users. These guidelines direct IS research to create purposeful artefacts which are considered DSR output having different characteristics: constructs, models, methods, and instantiations (March \& Smith, 1995; Hevner et al., 2004).

Improvements in artefact design knowledge are an essential component of design research (Hevner et al., 2004; Hevner, 2007). This understanding can be helpful in guiding IS design. Following this, it is important to extend design knowledge to ES, another field of specialised IS design. One of the methods for finding the application of a DSR methodology in ES development research requires the analysis of ES literature. Therefore, we attempted to conduct a qualitative content analysis to discover the application of DSR in existing ES design studies from the period 2005 to 2015 . The findings can be used to gather new design knowledge for developing and evaluating a specific ES by implementing MMC in assessing algebraic questions with multi-parts. These findings also constitute a case representation, as reported in this paper. 


\subsection{Issues of assessing multi-step questions}

Authentic assessment that focuses on measuring important skills - such as "intellectual quality" and making improvement in students' learning (Palm, 2008) - plays important roles in influencing students' approaches to learning (Price, Carroll, O'Donovan, \& Rust, 2011; Sangwin, 2012). Necessary steps should be taken to ensure that students' understanding of a domain is fulfilled by exploring their knowledge through assessment, which acts like a "bridge between teaching and learning" (Wiliam, 2005). Wiliam (2005) also explained the role of questions in a Japanese school, in which teachers spent a significant amount of time developing questions to measure their teaching success. Assessment is used to examine and report individuals' knowledge in a particular domain so that actions can be taken, based on the outcome of the assessment.

As the authenticity of assessment content is crucial, so too is the selection of an appropriate tool that determines how and what to assess. However, in mathematics, not all the assessments that are achieved using pencil and paper can be delivered using information technologies. Computer aided assessment (CAA) for mathematics is limited only to checking a final answer for multistage questions (Livne et al., 2007; Sangwin et al., 2009; Sangwin, 2012; Beevers et al., 1999). The only solution to this problem has been to apply a partial credit method which could award marks for a partially correct portion of the solution, even if the final answer was wrong (Beevers et al., 1999; Lawson, 2012). Many software packages for mathematical assessment have been developed, with the help of CAA software, to implement the partial credit concept. These software programs designed questions, collected answers and assessed them in the same way (Sangwin, 2012; Livne et al., 2007; Beevers et al., 1999).

Careful examination of the way in which questions have been redesigned to enable partial credit shows that this concept was first used in 1985. At this time, interactive past papers (IPP) - a computer aided learning in mathematics (CALM) project - designed questions using layers of steps that were made up of a single key-step and sub-sets that belonged to this key-step (Beevers et al., 1999). Students were given options either to provide the final answer in the keystep option or to select the sub-sets part if their intention was to be awarded a partial credit (Beevers et al., 1999).

Multi-step questions (MSQs) have been redesigned by breaking them into sub-questions that require only one stage to solve, thereby enabling the implementation of the partial credit concept. The idea of splitting complex questions raises problems with the assessment authenticity of these types of questions, due to the facts that (1) the choice and use of algorithms to solve the question are not in themselves tested, because methods are shown to the students and (2) a particular step is forced upon the students to follow, which might be new or hard to use (Lawson, 2012). The opportunity for giving valuable feedback is also reduced or lost, because the feedback information is based on the outcome of the assessment, the authenticity of which is doubtful. Therefore, the problem of assessing the students' full workings, while evaluating MSQs using CAA for Mathematics, can be classified as a wicked problem. In MMC, a student's ability to produce a final result can be determined by assessing the sequence of steps used to produce the steps and final answers (Genemo et al., 2015).

\section{Research Approaches}

\subsection{Research structure}

The objective of the study was initially to explore ES development literature to reveal the use of DSR as research methodology. To select relevant literature, specific criteria were set and qualitative content analysis was applied to inductively generate themes. The themes were then used as a basis to form categories that were matched for the presence of DSR as the ES development methodologies. The findings of the comparison determined the DSR approach for designing our specific ES, guided by the results of the content analysis of examination scripts in Mathematics. Figure 2 shows the steps taken in conducting the study. 


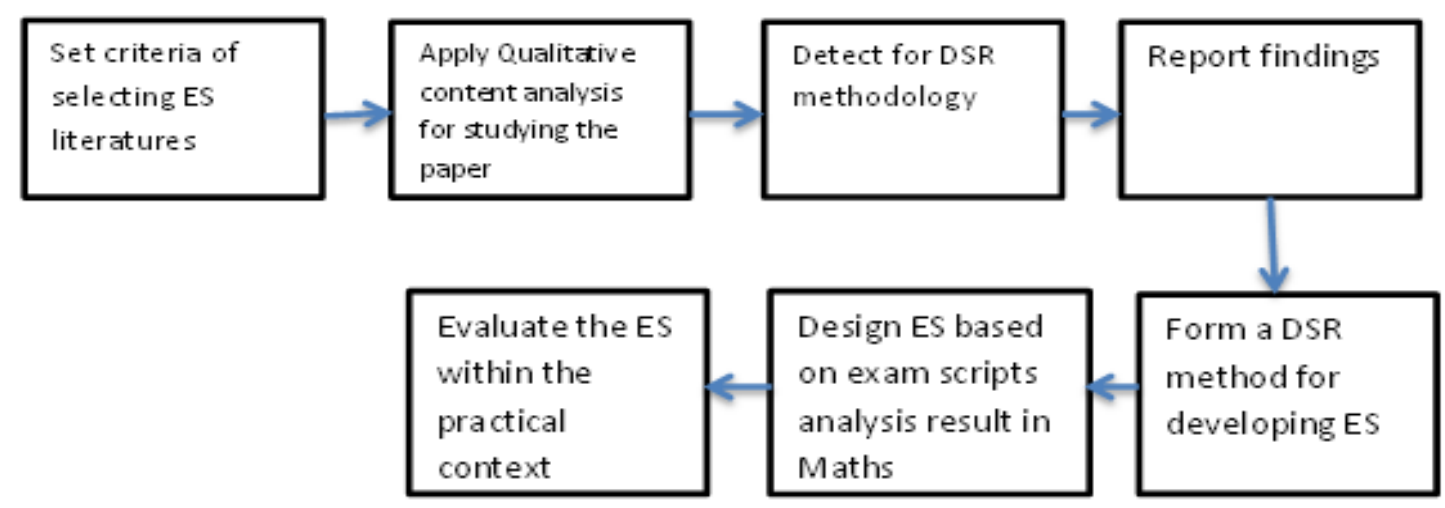

Figure 2: Steps of activities undertaken in the study

\subsection{Paradigm and methodologies}

The research paradigm influences "the practice of research and the practical research needs combination of philosophical ideas, general procedures and detailed methods" (Creswell, 2003, p. 8). J ohnson and Onwuegbuzie (2004) suggested that a research project should start with a theory followed by data collection that either supports or disproves the theory. In our study, when examining documents, we investigated their text with the aim of extracting information that would be utilised in forming criteria, knowledge and methodologies that would drive designing, building and evaluating the artefact, without requiring a theory to begin with. There were two purposes for investigating these text documents in this study. The first was to study the phenomenon related to discovering both development methodologies of ES artefacts by reviewing existing ES research articles. The second was to analyse the examined scripts to uncover errors and solution strategies that would be used as a basis for designing an ES. Therefore, we found that pragmatism was the most appropriate paradigm to conduct this research as the approach was not restricted to any particular philosophy, thus giving researchers the freedom to select "the methods, techniques, and procedures of research that best meet their needs and purposes" (Creswell, 2003).

Methodologies provide general procedures that determine the selection and use of research methods (Creswell, 2003; Crotty, 1998). The required research outputs help in selecting and using particular research methods (Crotty, 1998) - given that sufficient information about methodologies of research is vital for conducting IS research. Our research used a mixed methods approach since this approach is generally associated with the pragmatism paradigm. In the mixed methods approach, both qualitative and quantitative strategies and methods are used to collect and analyse data in a single study (J ohnson \& Onwuegbuzie, 2004; Creswell, 2003).

\subsection{Qualitative research method}

IS researchers need "to develop a rigorous, systematic inquiry" (Creswell, Hanson, Clark Plano, \& Morales, 2007, p. 236) to conduct research. This can be done by using qualitative, or quantitative, or mixed methods in a single research project. More details about qualitative research are given in the subsequent paragraphs.

Guest et al. (2013) suggest that it is important to define the purpose and focus of any qualitative study. Creswell (2003) argues that the purpose of qualitative research is "to understand a particular social situation, event, role, group, or interaction. Such research is largely an investigative process by which the researcher gradually makes sense of a social phenomenon by contrasting, comparing, replicating cataloguing and classifying the object of study" (Creswell, 2003, p. 226). Creswell's explanation of the function of qualitative research shows the significant roles that qualitative research plays in revealing rich information about phenomena. In the documents that we analysed, the phenomena that were investigated were 
the errors and solution strategies in the students' works, and insights that could be gleaned about ES development as the existing ES research articles were being reviewed.

The research question is considered to be the driver of the whole research. According to Ellis and Levy (2008), "the nature of what is going wrong - the problem - very much sets the parameters for what can be done" (p. 22). Creswell et al. (2007) also state that the research question "informs the approach or design used in qualitative research to collect and analyse the data" (p. 238). The most suitable research design is required if the identified qualitative research question is to be studied effectively. According to Creswell et al. (2007), there are five prevalent qualitative research designs which highlight "the procedures involved in actually conducting qualitative studies" (p. 237). Creswell et al. (2007) refer to research design as "approaches to qualitative research that encompass formulating research questions and procedures for collecting, analysing, and reporting findings" (p. 237). From the five qualitative research designs, the phenomenology design seems most appropriate for collecting and analysing documents (in our case, both forms of documents). However, the inductive content analysis suggested by Elo and Kyngäs (2008) seems more appropriate for the reason-building concepts and/ or categories from the content analysis of the documents.

Qualitative research has "an inductive and flexible nature" (Guest et al. 2013, p. 4), and the flexibility aspects offer the prospect of researchers being able to alter "the sampling proce-dures during the data collection process based on incoming data" (Guest et al. 2013, p. 4). In qualitative research, generally, the research questions are open-ended, to enable researchers to probe the problem for further information; this process of probing for more information leads to producing more-valid research data (Guest et al. 2013, p. 4). In our study, the research materials were approached with this type of open-ended relevant question in mind to allow us to thoroughly investigate the research objects iteratively. These qualitative research objectivities of identifying and exploring concepts and categories, describing, and explaining them, then assisted in accumulating the appropriate knowledge. The accumulated knowledge was then useful in constructing an ES artefact. These objectives can be contrasted with the purposes of qualitative research identified by Creswell (2003) - as discussed above.

\subsubsection{Qualitative document content analysis}

Content analysis is one of the qualitative and quantitative research methods that is applied to data obtained from human interaction processes - verbal or visual - and written documents for the purpose of analysing the data (Forman \& Damschroder, 2008; Mayring, 2000; Elo \& Kyngäs, 2008). In general, written data sources "can include published and unpublished documents, company reports, memos, letters, reports, email messages, faxes, newspaper articles and so forth" (Creswell, 2012, p. 223); this underlines the ability of researchers, in qualitative studies, to exploit documents as one of the important sources of information to explore phenomena. These documents are not restricted to one particular problem or domain.

The expansion of IS research into managerial and organisational issues has created greater interest in using qualitative research methods (Myers, 1997). There are many IS researchers who have been applying both qualitative and quantitative analyses in different research domains. For example, Al-Debei and Avison (2010) used content analysis in their examination of a business model in the field of IS using relevant literature, while Arnott and Pervan (2012) explored the DSR for DSS research articles employing a content analysis method. Indulska and Recker (2010) also conducted qualitative content analysis on DSR articles to establish the claims of these articles on usage of a DSR paradigm in their research. In our study, we followed this same path for two different purposes: 1) to analyse development methodologies in previous ES research articles and 2) to identify common errors and solution strategies in the examined scripts.

Deductive and inductive analyses are widely employed in qualitative research. Inductive analysis is an appropriate method when "there are no previous studies dealing with the phenomenon or when it is fragmented" (Elo \& Kyngäs, 2008). In our research, the phenomena in both types of documents needed to be evaluated using the inductive method, in particular for the classification and categorisation of the attributes in the phenomena. The categories 
were formed from the analysis of the ES articles and examination scripts. In general, the result of a qualitative content analysis is the summary of the original information and is presented in the form of concepts and/or categories that express the investigated phenomenon (Elo \& Kyngäs, 2008).

\subsection{Document analysis process}

The ES documents were collected to uncover information about the application of DSR in the ES development practices, while students' examination scripts were assembled for the exploration of common errors and question-solving strategies. In the absence of the usage of a DSR paradigm, the analysis focused on revealing methodologies utilised in developing ES artefacts. Each type of document was analysed for a different purpose, and the purposes that were selected were based on the criteria that they should contain qualitative data to answer the research questions. For the analysis process applied to ES articles, see Section 3.4.1; for examination scripts, see Section 3.4.2. Before and during the ES articles' content analysis processes, researchers frequently revisited and studied DSR articles - especially Hevner et al.'s (2004) design guidelines and Walls' (1992) information systems design theory (ISDT) - so that relevant data could be explored/observed and extracted. Also, in content analysis, "there are no systematic rules for analysing data" (Elo \& Kyngäs, 2008). However, as guidance to perform the analysis in our research, we followed the three phases stated by Elo and Kyngäs (2008): preparing, organising and reporting.

\subsubsection{ES article analysis}

The first concern in the preparation phase is to determine what to analyse that is pertinent to the research problems. The authors searched research library databases using the terms 'design science', 'expert systems', 'rule base' and 'rule based'. Extensive search efforts were made to find the specific type of ES research articles that employed a DSR paradigm in creating ES artefacts, but no research article had, at that time, been found. Therefore, we decided to look for the presence of information about basic components of ES; these are knowledge bases, knowledge elicitation techniques, knowledge representation techniques and inferenceengines, and design processes. The other conditions were that the ES articles should contain descriptions of ES design processes, evaluation methodologies and rigorous processes.

Once the purpose of analysis is determined, it is important to decide on the most suitable units of analysis. The selected ES articles having the specifications detailed above would be regarded as the relevant unit of analysis. For example, Kim and Kuljis (2010) employed content analysis of web-based content, in that they selected the profile page as the unit of analysis, using the rationale that the page contained enough data for their analysis to answer the research questions. Elo and Kyngäs (2008), referring to this issue, stated that "deciding on what to analyse in what detail and sampling considerations are important factors before selecting the unit of analysis". For our research, we faced challenges in resolving the sample and size of the ES articles to be gathered. Many of the articles that claimed to concern ES artefact development and implementation did not include the data that was required to fulfil our objectives. We therefore decided to choose the article selection measures based on the articles' content. According to Kim and Kuljis (2010), "what units need to be identified for sampling will be determined by the research question or hypothesis" (p. 373). As for the size of the sample used, for exploratory purposes, we accepted that the number of ES articles analysed was reasonable in our context of study; specifically, to discover ES creation and/ or developing methodological patterns.

More criteria were added to the ES article selection process. These criteria were (1) to include articles with publication dates from 2005 to 2015, (2) to exclude, as much as possible, articles published in unranked journals, (3) to exclude conference papers and (4) to include only rulebased ES types. The rationale for applying these criteria was to gather enough relevant and reliable sample articles. The reason for selecting only rule-based ESs was for the later implementation of MMC, when assessing MSQ solutions, using this type of ES; the lessons from the findings of the analysis were used in introducing the DSR paradigm into the 
development of the MMC ES artefact. Resolving the problems of choosing apposite articles helped us to move to the articles' content analysis process.

The actions that were taken in the preparation phase led to the gathering of 53 relevant rulebased ES articles. However, only 2o articles were analysed as they were the case representatives of the rule-based ES literature originated in different problem domains. The problem space defined in the selected 20 articles was somehow matched through to the five relevant characteristics of wicked problems. Also, these case representatives were somehow adopted different development methodologies that were analogous to DSR components. The researchers needed to familiarise themselves with the content of the articles. Elo and Kyngäs (2008) propose that researchers should fully explore the units to be analysed so as to comprehend the contents, and so that meaningful categories and/ or concepts can be developed from the analysis outcomes. "Document analysis involves skimming (superficial examination), reading (thorough examination), and interpretation" (Bowen, 2009). In our research, the skimming actions were performed during the gathering of the articles. The details of exploring the articles were accomplished during the organising phase. Table 1 shows the sources of the sample articles analysed in this study.

\begin{tabular}{|l|l|c|c|c|}
\hline \multicolumn{1}{|c|}{ Name of J ournals } & \multicolumn{1}{|c|}{$\begin{array}{c}\text { Publishers/ } \\
\text { countries }\end{array}$} & $\begin{array}{c}\text { Impact } \\
\text { factors/ } \\
\text { SCImago } \\
\text { ranking }\end{array}$ & $\begin{array}{c}\text { No of ES } \\
\text { published } \\
\text { articles }\end{array}$ & $\begin{array}{c}\text { Percentage of } \\
\text { published rule- } \\
\text { based ES } \\
\text { design articles }\end{array}$ \\
\hline $\begin{array}{l}\text { Expert Systems with } \\
\text { Applications }\end{array}$ & Elsevier, UK & $2.53 / \mathrm{Q} 1$ & 5 & $25 \%$ \\
\hline Decision Support Systems & Elsevier, UK & $2.4 / \mathrm{Q} 1$ & 2 & $10 \%$ \\
\hline $\begin{array}{l}\text { Int. J. of Computer and } \\
\text { Communication Tec. }\end{array}$ & $\begin{array}{l}\text { Inder-science, } \\
\text { India }\end{array}$ & $2.40 / \mathrm{Q} 4$ & 1 & $5 \%$ \\
\hline The Arts in Psychotherapy & Elsevier, UK & $0.79 / \mathrm{Q} 3$ & 1 & $5 \%$ \\
\hline $\begin{array}{l}\text { Int. J. of Science and } \\
\text { Modern Engineering }\end{array}$ & IJ ISME, India & $1.07 / \mathrm{Q} 4$ & 1 & $5 \%$ \\
\hline $\begin{array}{l}\text { Int. J. of Computer } \\
\text { Science }\end{array}$ & IJ CSI, & $0.44 / \mathrm{NA}$ & 1 & $5 \%$ \\
\hline Assembly Automation & Emerald, US & $0.91 / \mathrm{Q} 2$ & 1 & $5 \%$ \\
\hline $\begin{array}{l}\text { Automation in } \\
\text { Construction }\end{array}$ & Elsevier, UK & $2.51 / \mathrm{Q} 1$ & 1 & $5 \%$ \\
\hline $\begin{array}{l}\text { J of Software Engineering } \\
\text { and Applications }\end{array}$ & $\begin{array}{l}\text { Scientific } \\
\text { Research }\end{array}$ & $0.94 / \mathrm{NA}$ & 1 & $5 \%$ \\
\hline $\begin{array}{l}\text { Int. J. Intelligent Systems } \\
\text { and Applications }\end{array}$ & $\begin{array}{l}\text { Modern } \\
\text { Education and } \\
\text { Computer Science }\end{array}$ & $0.38 / \mathrm{NA}$ & 1 & $5 \%$ \\
\hline $\begin{array}{l}\text { Electrical Power and } \\
\text { Energy Systems }\end{array}$ & Elsevier, UK & $2.19 / \mathrm{Q} 1$ & 1 & $5 \%$ \\
\hline $\begin{array}{l}\text { Computer-Aided Civil and } \\
\text { Infrastructure } \\
\text { Engineering }\end{array}$ & Willey, US & $4.90 / \mathrm{Q} 1$ & 1 & $5 \%$ \\
\hline $\begin{array}{l}\text { Educational Technology \& } \\
\text { Society }\end{array}$ & $\begin{array}{l}\text { IEEE Computer } \\
\text { Society, US }\end{array}$ & $0.82 / \mathrm{Q} 1$ & 1 & 2 \\
\hline $\begin{array}{l}\text { Knowledge Based } \\
\text { Systems }\end{array}$ & Elsevier, UK & $2.70 / \mathrm{Q} 1$ & 2 & $5 \%$ \\
\hline
\end{tabular}

Table 1: Sources of samplearticles

In the organising and reporting phases, the inductive content analysis comprises "open coding, creating categories and abstraction" (Elo \& Kyngäs 2008, p. 109). According to Elo and Kyngäs (2008) during the open coding, researchers are meant to take notes and headings in the text while reading the sample. In our research, the gathered copies of the ES articles were saved in 
hard and electronic formats. In the electronic format, headings and notes were added as comments to the articles while they were being read. Similarly, text highlighting, copying and pasting each article's selected content were used to gather and code relevant data. Further reading of the commented articles resulted in correcting and/ or adjusting the coded data to ensure the collection of apt and sufficient data from the articles. Here, the act of selecting headings was to form a new categorisation (Elo \& Kyngäs, 2008). Elo and Kyngäs (2008) also refer to the categorisation process as including the interpretation process, which helps with grouping into categories; these categories are then used to describe the phenomenon that has been analysed. In our study, the headings that emanated from the articles' coding process were grouped to create categories, and these categories were regrouped under higher order headings or categories. Figure 3 shows the categories that have been inductively generated in our study.

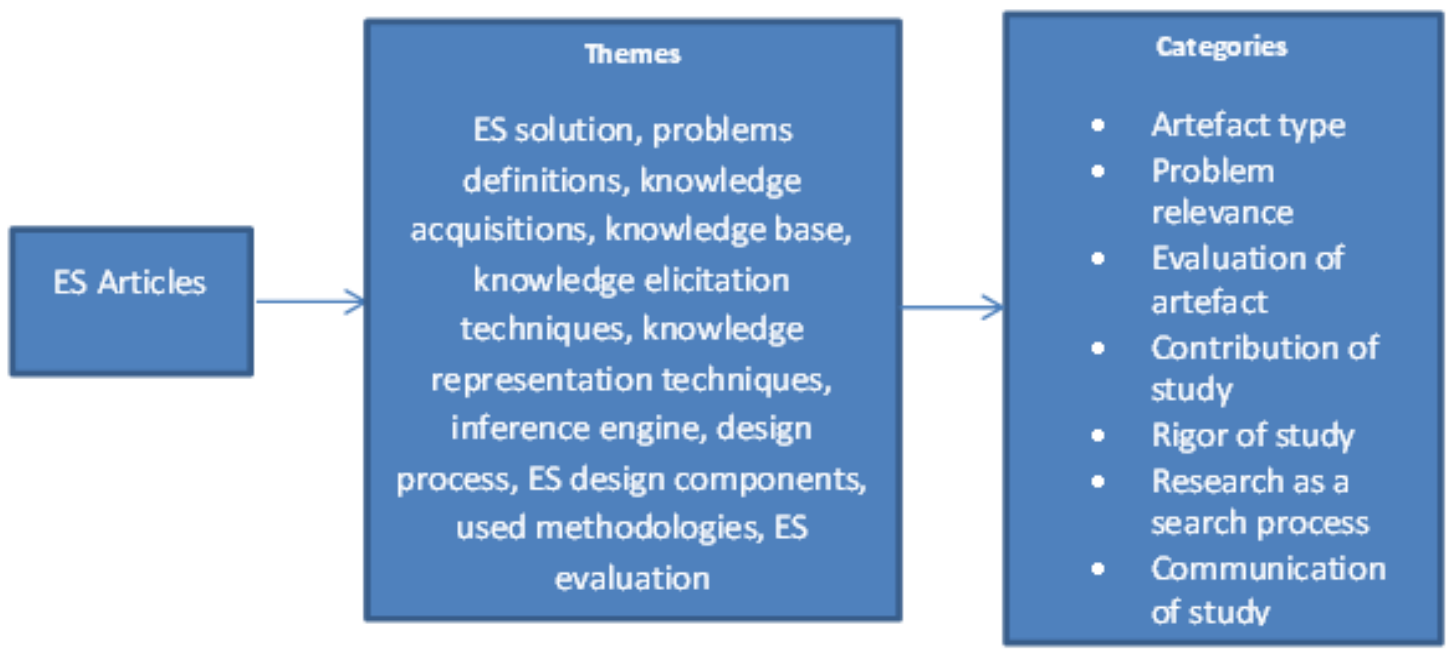

Figure 3: Categories that have been inductively generated through the themes

In this analysis, 15 themes were inductively generated from the samples. The themes that were based on the key elements of ES design methodology can be informed through the seven category names. Although we found a few inconsistent remarks in generalising the categories, in general (1) the description of an ES solution helped to determine artefact types and its purposes, (2) both descriptions related to problem definitions and knowledge acquisition details informed us on problem relevance, (3) the description of ES solution evaluation denoted the artefact's evaluation, (4) descriptions of the design process, components and knowledge representation indicated the contribution of the study, (5) the details related to used methodologies and approaches gave rigour of the study, (6) appropriate approaches used in designing the inference engine denoted the research as a search process and (7) the details related to the ES evaluation method defined how the ES design is communicated to its target audience. We matched these categories with Hevner et al.'s (2004) definition of seven principles, and through these we anticipated that the activities of ES design research - such as those used for identifying problem relevance and overall design and evaluation of the ES artefact - can be well-recognised and accomplished to achieve design research outcomes. The following reporting phase gives details on how the categories are reported as part of our study.

The process of abstraction takes the following steps: (1) generating categories that reflect the general description of the themes using category names that describe the characteristics that the categories refer to, (2) iterating the abstraction process until the categories' representation of the general description of the phenomena is satisfactory and (3) grouping the subcategories that share similar specifications under higher order categories. The created categories in Figure 3 were used to explain the development methodologies of ES artefacts and processes through the creation of general categories that reflect "content-characteristic words" (Elo \& Kyngäs, 2008); that is, 15 themes. These category names replicate the keywords and terminologies that are used in the development of ES artefacts. Finally, in the reporting phase, 
we reported the findings through the skeleton of Hevner et al. (2004) as discussed above. In Appendix A the details can be viewed in Table A1.

\subsubsection{Examination script analysis}

In any ES development, the knowledge base is one of the main components of an ES artefact. In our target problem domain, one of the knowledge sources was examination scripts that were required for analysis in designing the $\mathrm{ES}$. The insights obtained from the selected scripts were able to provide relevant data to answer pertinent research questions related to the phenomenon of a MSQs solution assessment by applying the MMC method. The criteria - to include questions from the scripts in the qualitative analysis study - were carefully examined and documented. In this, we used mathematical knowledge to decide appropriate criteria for question selection.

In the preparation phase, there are several factors that determine the selection of the unit of analysis. This unit is determined by the nature of the question that has been selected from the scripts; that is, the scripts must contain theappropriate knowledge to beassessed through their reasonable question solution. The knowledge domains that we assessed in these examinations were (1) solving linear equations using the elimination method and back substitution and (2) integration using a substitution technique and by parts. Both types of question's solutions require steps that use an algorithm to produce the final answers. The comprehension of detailed domain knowledge assists the researcher in deciding on the type of documents to be analysed to solve the research problems. The appropriate domain knowledge is checked to confirm the data's integrity and the validity of the content analysis outcome. The data in the question's solution can be used to identify solution strategies and possible errors in the student's solution. Using the scripts' domain knowledge criteria, we collected 732 scripts.

The scripts were scanned to define the sample size and specification. To achieve these, the scripts were divided into subjects; then, related questions were regrouped within the defined subjects. The rearranged questions were also segmented into two groups based on the marks awarded by the examination assessors to the questions' solutions. Questions whose solutions could attain a possible score of 6 marks were split into two groups. Those questions whose solutions could attain part marks of 0-3 were allocated to one group. The second group was composed of questions whose solutions could attain part marks of 4-6. Questions whose solutions could attain part marks of only 3 or 4 were assigned to either group. The samemethod was applied to questions that had 5 marks assigned to a correct solution. In this subdivision, the questions solutions with lower awarded marks that have 0-2 marks grouped together, while the others with the marks 3-5 was grouped in different set. Again in this group, with 5 with full mark, questions solutions with marks 2-3 were assigned to the lower or higher mark group.

The above mentioned grouping of scripts formed our sampling process. Equal numbers of scripts, from each subject, containing equal number of low and high marks were chosen for the document analysis process. Out of 732, only 532 scripts were selected through the sampling process. In the current paper, as the analysis process is on-going, laborious as well as time consuming, 45 examination scripts as case representatives were selected for the analysis process; these scripts were combined from 3 different examinations of the Mathematical foundational subject. The knowledge examined in the questions was the same, although variations in the variables' labels and coefficient values were different. Half of the scripts contained solutions whose questions lay within a low range of marks, while the other half lay within the higher range of marks. As mentioned above, the scripts were divided based on the subject, related questions and the number of marks given to the students' work. Considering rules of research ethics (defined in our approved ethical application), weremoved theidentities of students from the scripts, numbered each script, then copied the pages that included the solutions to be analysed. Each copied page was given the script number. Wekept the details of the subject and the examination-year of the scripts. The list of each question's information, showing where it originated, assisted us to track questions; this tracking process was very useful during the code formation, collection and grouping processes. 
The organising phase involved induction analysis. The copied questions' solution scripts were examined and the open coding actions - which involved evaluating the algorithm applied, and the results of applying it - were performed. The explorations revealed whether the correct solution strategies had been applied to solve the questions, and whether or not any errors had been made during the method's application. The relevant codes were recorded in a separate note so as to keep the original data intact, because further re-reading was required to readjust the initial observation and/ or to add more code to elicit more relevant data from the scripts; therefore, it was important to use separate media to record the analysis activities and findings. We discovered the importance of this issue during script analysis, when adding heading and titles to the script itself accidently erased the original script information; this led to discarding that script from the scripts' analysis list. At the completion of the coding process another 7 scripts were excluded because they did not encompass examinable information to resolve or assist in answering the research questions. The next process was to gather all these codes from our note-book record to form categories.

As for the solution strategies that were used by learners, general categories that are shown in Figure 4 (comprising Figures A, B and C) have been constructed. The applied strategies can be compared to the expected, taught methods to find out how much these strategies deviate from the expected solution methods. This is possible by conducting statistical analysis to realise the frequency of these solution methods by students. A description of the formation of these categories is presented in the next section.

The selected questions in the subject (called Engineering Mathematics 1) asked the problem solvers to find the values of variables using matrix methods. Although the steps followed in the examination solution's scripts of 2011-2015 were the same, the coefficients of the equations' variables, and the values assigned to equations, were different in each examination. Therefore, each year's examination solutions were analysed separately to collect solution methods that applied in the elimination of variables, and the computation of variables' values. The errors made in the examination scripts were similar; therefore, these errors could be categorised together and checked for the frequency of errors. Figure 4 (A) shows the categories that display equations and variables belonging to the equations; Figure 4 (B) shows the Variables category and its sub-categories related to the variables' elimination process along with the result of the elimination process; Figure 4 (C) shows the variables' Values finding process categories and its sub-categories, and the possible outcomes of the variables' value-finding process.

The categories that were produced from the qualitative content analysis result were then used as a source to create a questionnaire to be employed in the quantitative content analysis phase. The questionnaire was used to collect quantitative data from examination scripts that had been reserved for the quantitative phase study. The scripts having the same types of content were divided - using the same criteria mentioned above - into two groups. One group was analysed using a qualitative content analysis method while the other group was set aside for the quantitative content analysis method. In this paper, we have excluded the details of the quantitative content analysis. 


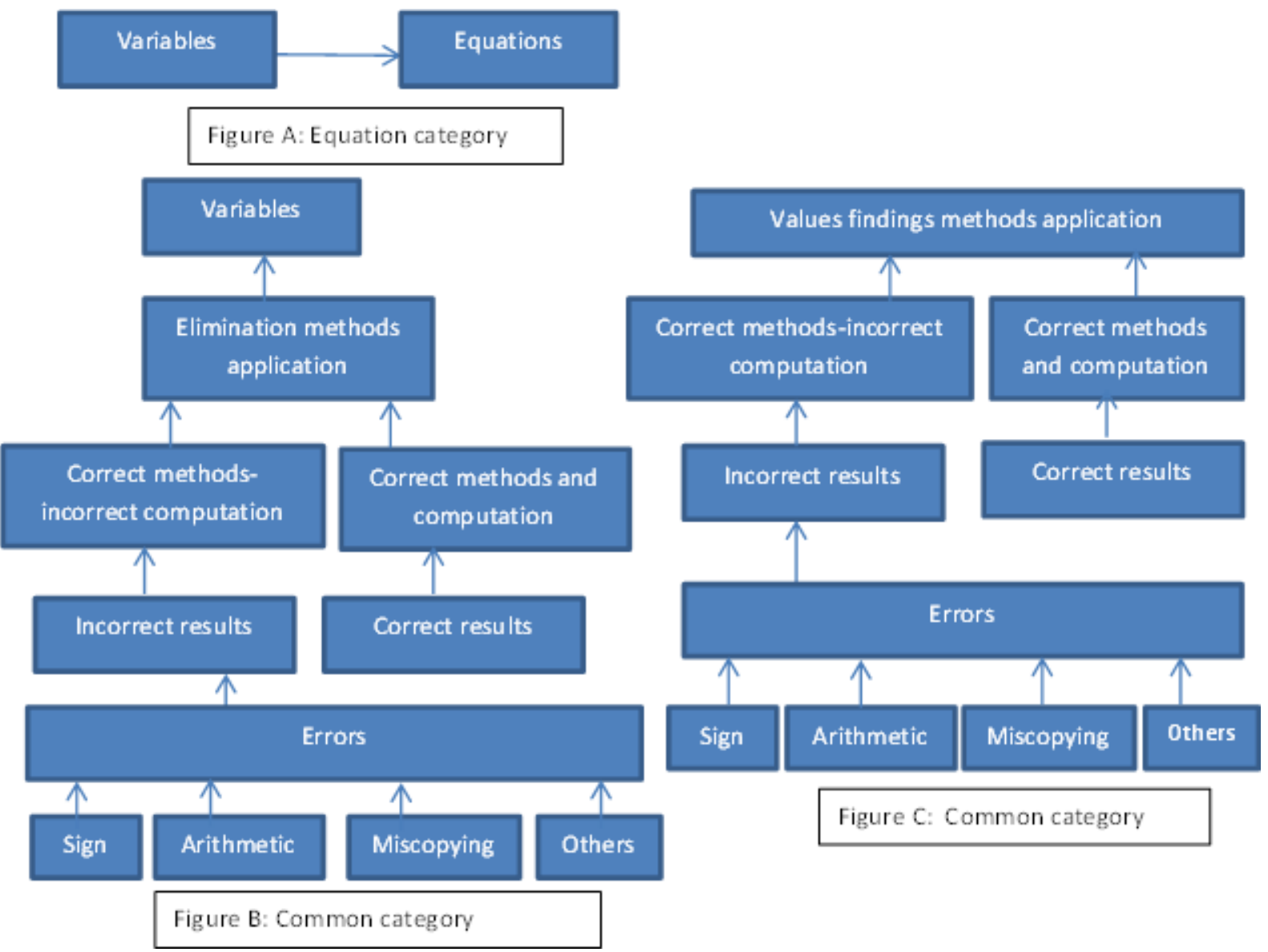

Figure 4: Categories formed from the 82 examination scripts' analysis

\subsection{ES artefact development method}

Motivated by the demonstrated use of DSR in ES design, we employed Hevner et al.'s (2004) seven guidelines for conducting our design study to develop the MMCES artefact. As a specific approach to ES development, we justified the seven guidelines through the traditional phases of Waterman's (1986): identification, conceptualisation, formalisation, implementation and testing. Waterman's phases have been demonstrated as being in general use over recent years for ES development. On the other hand, Hevner's guidelines are generally applicable to any IS research. We have established an association between Hevner's guidelines and Waterman's ES development phases to show how the DSR approach can offer benefits in the development of the MMC ES artefact (see Figure 5 below). 


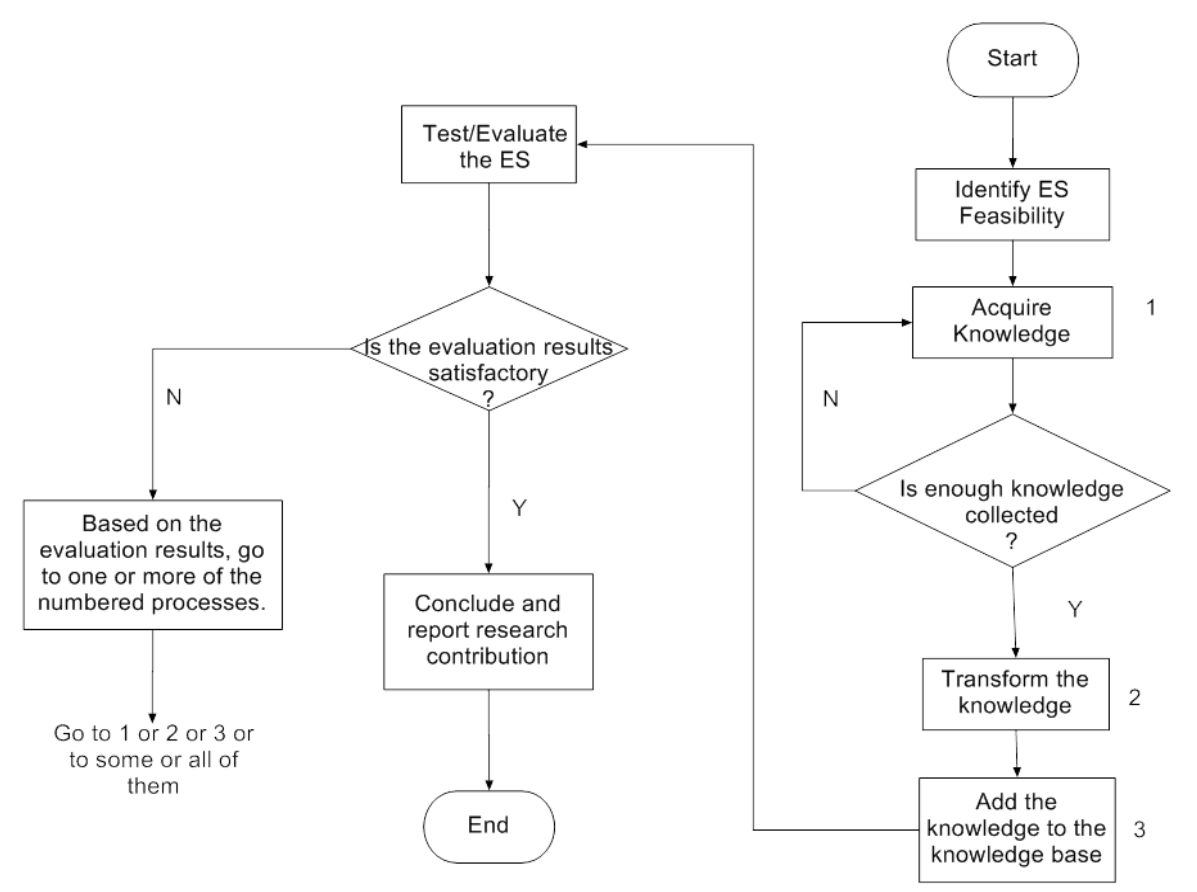

Figure 5: Development Phases of the MMC ES artefact

In the identification phase - conforming to Hevner et al.'s (2004) "design as artefact and problem relevance" guideline - the research requirements were identified through the research questions' phenomena studies and the literature review, which identified related knowledge and issues that required further research investigation. The conceptualisation phase conformed to Hevner et al.'s (2004) "research rigour and design as a search process" guidelines. In this phase, elements in the document analysis findings were searched and relationships between them established; interactions between elements and the interactions' controls were also determined in this phase.

The formalisation phase conformed to Hevner et al.'s (2004) "design as a search process" guideline. At this stage, the knowledge that was obtained in the conceptualisation phase was transformed into a useable form for ES design. At the implementation phase - conforming to Hevner et al.'s (2004) "design as a search process" guideline - the formatted knowledge was stored in the ES for the effective assessment operation. The testing phase conformed to Hevner et al.'s (2004) "design evaluation" guideline, which verified theelement's existence, thevalidity of relationships and interactions, and the artefact's performance and utility. Table 2 shows the details of the processes illustrated in Figure 5. The flowchart sequences and activities (in Figure 5) are based on Waterman's ES development phases and Hevner et al.'s (2004) guidelines. 


\begin{tabular}{|l|l|}
\hline Identify ES feasibility & Identifying requirements for possible devlopment of ES. \\
\hline $\begin{array}{l}\text { Acquire knowledge } \\
1\end{array}$ & $\begin{array}{l}\text { Continue extracting knowledge from document analysis findings } \\
\text { (errors and solution algorithms and classifying them into groups) until } \\
\text { satisfied that enough knowledge is acquired. }\end{array}$ \\
\hline $\begin{array}{l}\text { Transform the knowledge } \\
2\end{array}$ & $\begin{array}{l}\text { Transform the acquired knowledge and do this rigorously until } \\
\text { sufficient knowledge is transformed into the format that is recognised } \\
\text { by the ES. }\end{array}$ \\
\hline $\begin{array}{l}\text { Add the knowledge to the } \\
\text { knowledge base 3 }\end{array}$ & $\begin{array}{l}\text { Put the knowledge into the knowledge base and run the ES prototype. } \\
\text { This is the implementation phase of the ES. }\end{array}$ \\
\hline Test/ evaluate the ES & $\begin{array}{l}\text { Test the system for the processes in the boxes numbered 1-3. Also } \\
\text { validate the performance and utility of the ES. }\end{array}$ \\
\hline $\begin{array}{l}\text { Based on the evaluation } \\
\text { results, go to one or more } \\
\text { of the numbered } \\
\text { processes. 1, 2, 3 }\end{array}$ & $\begin{array}{l}\text { If the evaluation feedback requires modification, go to the processes 1, } \\
\text { or 2 or 3 or combination of them to satisfy the requirements in the } \\
\text { feedback returned by the evaluation/ test phase. }\end{array}$ \\
\hline $\begin{array}{l}\text { Conclude and report the } \\
\text { research contribution }\end{array}$ & $\begin{array}{l}\text { This shows the end of successful artefact development and, as the } \\
\text { result, communicate the research contribution to the knowledge base. }\end{array}$ \\
\hline
\end{tabular}

Table 2: Details of processes in the MMC ES artefact Development Phases flowchart

\section{ES Artefact Design}

Walls et al. (1992) provided a framework to describe the design artefact. The framework is wellknown as Information Systems Design Theories (ISDT) for effectively guiding the artefact design within a problem context. Weadopted this framework to define the artefact as a solution model, through the components of design such as meta-requirements, meta-design, kernel theories and testable hypothesis. Table 3 shows the details of the ES artefact.

The architecture of the MMC ES artefact is shown in Figure 6; it includes the knowledge base, knowledge source, blackboard, inference engine, and user interface. The information - facts and rules - in the knowledge base that is required for the operation of the MMC ES artefact is constructed from the knowledge source. The blackboard module - also called the working memory in rule-based ES - is a medium acting as a database; its purpose is to store data about a specific case of the current problem that the ES is focusing on (Sasikumar et al., 2007). The inference engine takes input from users and attempts to resolve problems using the control through the rule-based technique. The purpose of the user interfaceis to allow users to interact during the operation of the artefact. 


\begin{tabular}{|c|c|c|}
\hline $\begin{array}{l}\text { Theory } \\
\text { component }\end{array}$ & Description & As evident in this research \\
\hline \multicolumn{3}{|l|}{ Design Product } \\
\hline Meta -requirements & $\begin{array}{l}\text { Class of problems to which } \\
\text { theory applies }\end{array}$ & $\begin{array}{l}\text { Wicked problem, complex problems that are } \\
\text { made up of many interrelated elements, } \\
\text { assessment using MMC }\end{array}$ \\
\hline Meta-design & $\begin{array}{l}\text { Class of artefacts that meet } \\
\text { meta-requirements }\end{array}$ & $\begin{array}{l}\text { Rules based approach, procedural and } \\
\text { declarative knowledge formation, solution } \\
\text { steps tracking }\end{array}$ \\
\hline Kernel theories & $\begin{array}{l}\text { Theoretical grounding of } \\
\text { the design product }\end{array}$ & $\begin{array}{l}\text { Knowledge of assessment (theories for what to } \\
\text { be assessed) concept by Bloxham and Boyd } \\
\text { (2007); theories of Anderson (1988) for } \\
\text { declarative knowledge }\end{array}$ \\
\hline $\begin{array}{l}\text { Evaluation of } \\
\text { design product } \\
\text { outcomes }\end{array}$ & $\begin{array}{l}\text { Reflection and evaluation of } \\
\text { artefact in use setting }\end{array}$ & $\begin{array}{l}\text { Descriptive method also seems appropriate for } \\
\text { evaluating MMC artefact model while for } \\
\text { method and instantiation artefacts, testing and } \\
\text { analytical approaches will be utilised. }\end{array}$ \\
\hline \multicolumn{3}{|l|}{ Design Process } \\
\hline Design method & $\begin{array}{l}\text { Procedures adopted for } \\
\text { design and co-constructing } \\
\text { artefact }\end{array}$ & $\begin{array}{l}\text { Content analysis in the process of DSR for } \\
\text { artefact design }\end{array}$ \\
\hline Kernel theories & $\begin{array}{l}\text { Theoretical grounding of } \\
\text { the design process }\end{array}$ & $\begin{array}{l}\text { Assessment theory in designing to the } \\
\text { requirements, and Math knowledge (based on } \\
\text { MMC) and by applying the design guideline } 6 \\
\text { of Hevner et al. (2004) }\end{array}$ \\
\hline $\begin{array}{l}\text { Evaluation of } \\
\text { design process } \\
\text { outcomes }\end{array}$ & $\begin{array}{l}\text { Reflection and evaluation of } \\
\text { design process in relation } \\
\text { to achievement in terms of } \\
\text { achievement of meta- } \\
\text { requirements, and meta- } \\
\text { design }\end{array}$ & $\begin{array}{l}\text { We evaluated the artefact in all design and } \\
\text { development phases. }\end{array}$ \\
\hline
\end{tabular}

Table 3: The design details of the MMC ES artefact

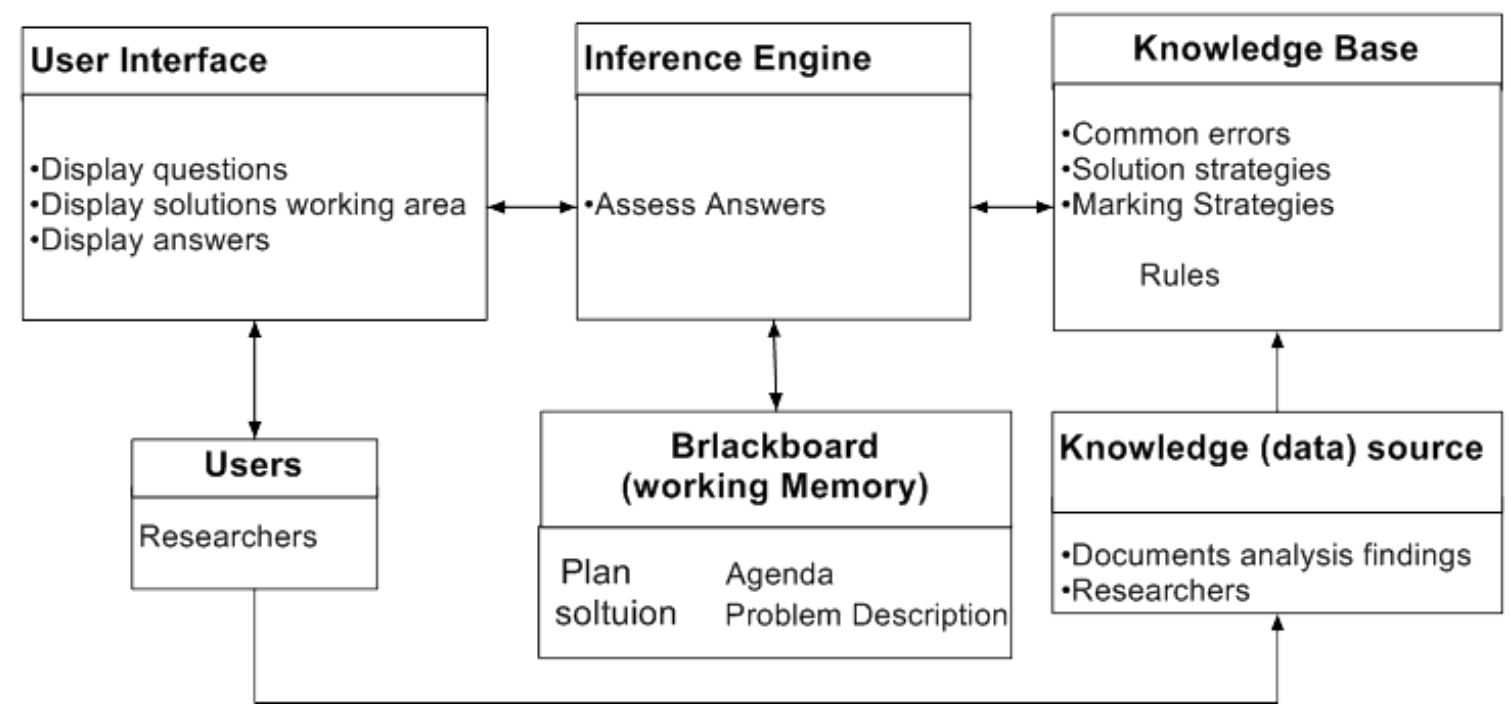

Figure 6: Overall architecture of the proposed solution artefact

\subsection{Assessing MSQ Questions' Solutions}

Figure 7 illustrates the operational process of the proposed ES artefact to assess an MSQ solution. Theinference engine uses available knowledge to determine if there is knowledge that 
can be used for the step solution submitted by a user. If there is no solution, the system records the reason for the absence of the solution and checks if all the steps that are required to answer the question have been fully used. If the knowledge to assess the current step is available, the system assesses the solution at that step, assigns a mark to it, and gives the user the choice to continue to the next step or to stop answering the question. If all the steps are completed, or the user has requested to end the assessment process before answering the question fully, the system adds the steps' marks, and displays the total mark. That ends the assessment process.

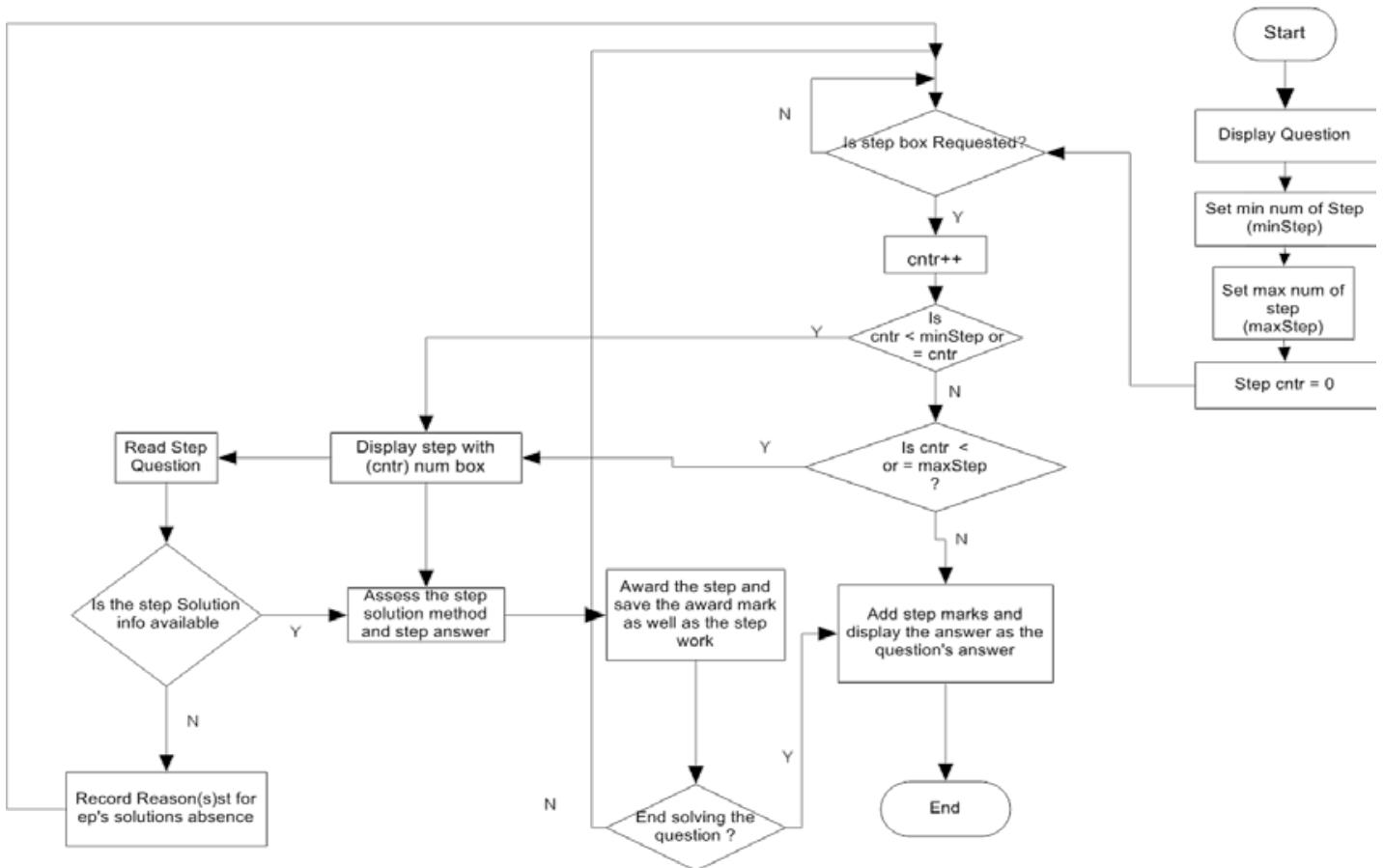

Figure 7: Working principle of the proposed solution artefact

The MMC ES artefact function is based on providing questions, an answer, and feedback as well as working areas for users. Users select the number of steps that the current question requires to produce the final answer, and go through each step to work on the step's answer. The final step would be the answer to the MSQ. At any time, users can stop working on the current step's solution and submit the whole answer to end the current question's answering process or session. The system displays each step's answers based on the number of steps answered. Our ES artefact assesses and awards answers to steps in questions based on the criteria set by the assessors, who have the privilege to prepare question and assessment criteria for storing in the system. At the end of the session, or upon the request of the users, the current question's answer, with feedback, is displayed. The system allows developers to add features to the functionality of the MMC ES artefact, such as modifying or adding knowledge to the knowledge base or setting new rules. If the artefact is not able to assess the user's submitted solution, the artefact saves the submitted solution, giving developers or/ and assessors the opportunity to review and take actions that enhance the artefact's functionality.

\section{ES Artefact Evaluation}

The type of evaluation criteria are determined by the research problems, the objectives of designing problems solutions, and the research questions that are originated in the particular environment (Hevner et al., 2004; Vaishnavi and Kuechler, 2015). The two phenomena that have been explored in this article are ES development research articles and the content of examination scripts. The process of evaluating the two sources began at the point where the research problems were established; the criteria and methodology utilised to analyse the two types of documents have been explained in detail in the content analysis sections, and these criteria, and the methodology, included the evaluation process. 
For the evaluation of the ES artefact, we used an experimental approach as it is one of the defined evaluation methods in Gregor and Hevner (2013). The criteria that govern or control the evaluation execution or process is based on the findings and knowledge of the examination scripts and ES articles' content analyses. The findings from the analysis of examination scripts revealed the complexity of the nature of implementing MMC using an IT artefact. Gregor and Hevner, (2013) suggested that the evaluation process should go through a proof-ofdemonstration to confirm the significance and value of the artefact. Therefore, the proposed ES is evaluated in terms of its validity, utility, quality and efficacy. For the research contribution to be credible, the design evaluation should clearly reveal the practical contribution that the research has made to the application's context/ environment (Gregor and Hevner, 2013). The practical contribution of the proposed artefact is then demonstrated through the system functions using the MMC approach. Within the capacity of our artefact as a model demonstration, the design approach was guided by the target problem-specific details. Further improvements are required to make the artefact completely instantiated to realise MMC for its quality and efficacy. In relation to the validity of the proposed artefact, Figure 7 showed the key elements of the findings that have been executed in the solution strategies of the ES.

\section{Discussion And Conclusion}

This study has reinforced the application of DSR knowledge for ES development studies. We investigated its current status and suitability for showcasing an ES design using DSR that was guided by context-specific findings in a practical problem context. The proposed artefact has been called the MMC ES artefact, because our solution strategy was based on the method marking concept. To investigate the relevant ES design literature we adopted a qualitative content analysis to inductively generate themes. The themes of ES design were used as a basis to form categories that were matched for the presence of DSR, and represented its applications as the ES development methodology. The findings of the comparison determine importance of DSR approach for designing our specific ES guided by the result of the content analysis of examination scripts in Mathematics.

The primary contribution of the study is that by conducting a rigorous DSR study using content analysis, we developed basic knowledge about the target artefact design. Further, we introduced the adaptation of content analysis to conduct DSR projects. We have demonstrated how an ES artefact should be designed through investigating phenomenon relevant to a literature base and practical application area. The two phenomena that have been explored in this article are ES development research articles and examination script content. The process we generated to evaluate the two sources started from the point where the research problems were outlined; the criteria and methodology utilised to analyse the two types of documents have been explained in detail.

The secondary contribution of the study is that it has described an innovative ES artefact design by showcasing it in addressing a practical problem in the education domain. We used Walls et al.'s (1992) ISDT framework to define the proposed ES artefact through the components of design such as meta-requirements, meta-design, kernel theories and a testable hypothesis of the artefact as a product. According to Walls et al.'s (2004) different levels of usage of ISDT framework, we fulfilled the conditions of level 1 - knowledge contribution that represents studies that define design features and requirements of a new class of IS design, when they use the Walls' framework. We also approached level 2 - knowledge contribution, as we also outlined the meta-requirements for the new class of IS (e.g. MMC ES artefact) and its instances.

Mainstream IS researchers over the past decades have shown limited interest in ES development research of the type reflected in our results of the content analysis. None of the top eight IS journals (Information Systems J ournal, Information Systems Research, European J ournal of Information Systems, J ournal of Information Technology, J ournal of Management Information Systems, Management Information Systems Quarterly, Information and 
Management, and Journal of the Association for Information Systems) published fully developed rules-based ES development studies. However, several engineering and other domain-specific journals, indicated in Table 2, published fully-researched ES design articles to meet the demand for knowledge in the field.

Although our contribution is an initial solution model, the work described in this paper has defined the relevance and importance of the artefact, which shows its competence to implement MMC and make valuable contributions to the education problem domain. Being able to assess the complete working of learners' solutions to questions has major advantages for all stakeholders - learners, educators, policy makers and any allied bodies in the education and associated domains. An assessment outcome can influence teaching and learning methods and contents. The same concept can be applied in similar domains, such as physics, chemistry and any other discipline where solutions to wicked problems are required. There are many factors that might affect the functional characteristics of MMC artefacts being built; these are the data source selection criteria, methods and types of knowledge extracted, and the extent of design and evaluation involved. Future research will be needed to minimise the limitations associated with the functionality of these artefacts.

\section{References}

Al-Debei, M. M. and Avison, D. (2010). Developing a unified framework of the business model concept. European J ournal of Information Systems, 19, 359-376.

Alter, S. (2008). Defining information systems as work systems: Implications for the IS field, European J ournal of Information Systems, 17(5), 448-469

Anderson, J . R. (1988). Foundations of intelligent tutoring systems, Lawrence Erlbaum Associates, Inc., Publishers, NewJ ersey.

Andersen, M. Gagne, J ML and Kleindienst, S (2013). Interactive expert support for early stage full-year daylighting design: a user's perspective on Lightsolve, Automation in Construction, 35, 338- 352

Angeli, C. (2010). Diagnostic Expert Systems: From Expert's Knowledge to Real-Time Systems, In Advanced Knowledge Based Systems: Model, Applications \& Research (Eds. Sajja \& Akerkar), 1, 50 - 73

Arnott, D. and Pervan, G. (2008). Eight key issues for the decision support systems discipline, Decision Support Systems, 44(3), 657-672

Arnott, D. and Pervan, G. (2012). Design science in decision support systems research: An assessment using the Hevner, March, Park, and Ram Guidelines. Journal of the Association for Information Systems, 13, 923-949.

Arnott, D. and Pervan, G. (2014). A critical analysis of decision support systems research revisited: the rise of design science. J ournal of Information Technology, 29(14), 269293.

Beevers, C., Wild, D., McGuire, G., Fiddes, D., \&Youngson, M. (1999). Issues of partial credit in mathematical assessment by computer, Research in Learning Technology, 7(1), 2632.

Benbasat, I., and Zmud, R. W. (1999). Empirical Research in Information Systems: The Practice of Relevance, Management Information Systems Quarterly, 23 (1) 3-16.

Bloxham, S., and Boyd, P. (2007). Developing Effective Assessment In Higher Education: A Practical Guide: A Practical Guide: McGraw-Hill Education,UK.

Boulos, M. N. K. (2012). Expert system shells for rapid clinical decision support module development: an ESTA demonstration of a simple rule-based system for the diagnosis of vaginal discharge, Healthcare Information Research, 18, 252- 258. 
Bowen, G. A. (2009). Document analysis as a qualitative research method. Qualitative research journal, 9, 27-40.

Creswell, J . (2003). Research design: Qualitative, Quantitative, and Mixed Methods, Sage Publications, California, USA.

Creswell, J. W. (2012). Educational Research: Planning, Conducting, And Evaluating Quantitative, Pearson.

Creswell, J . W., Hanson, W. E., Clark Plano, V. L., and Morales, A. (2007). Qualitative Research Designs: Selection and Implementation, The Counselling Psychologist, 35(2), 236-264

Crotty, M. (1998). The Foundations Of Social Research: Meaning And Perspective In The Research Process.

Coussement, K., Benoit, D.F., and Antioco, M. (2015). A Bayesian approach for incorporating expert opinions into decision support systems: A case study of online consumersatisfaction detection, Decision Support Systems, 79, 24- 32.

Durkin, J . (1994). Expert Systems: A View of the Field, IEEE Expert: Intelligent Systems and Their Applications, 11(2), 56-63.

Ellis, T. J . and Levy, Y. (2008). Framework Of Problem-Based Research: A Guide For Novice Researchers On The Development Of A Research-Worthy Problem. Informing Science: International J ournal Of An Emerging Transdiscipline, 11, 17-33.

Elo, S. and Kyngäs, H. (2008). The Qualitative Content Analysis Process. J ournal of Advanced Nursing, 62, 107-115.

Forman, J . and Damschroder, L. (2008). Qualitative Content Analysis. Empirical Research For Bioethics: A Primer. Oxford, UK: Elsevier Publishing, 39-62.

Genemo, H., Miah, S.J and McAndrew, A. (2015). A design science research methodology for developing a computer-aided assessment approach using method marking concept, A design science research methodology for developing a computer-aided assessment approach using method marking concept, Education and Information Technologies, 10.1007/ s10639-015-9417-1, 1-16

Giarratano, J. C. and Riley, G. (2005). Expert Systems: Principles And Programming, Cambridge, Mass.: 4th Ed.,Thomson Course Technology

Gregor, S. and Hevner, A. R. (2013). Positioning And Presenting Design Science Research For Maximum Impact. Management Information Systems Quarterly, 37, 337-356.

Guest, G., Namey, E. E. and Mitchell, M. L. (2013). Collecting Qualitative Data: A Field Manual For Applied Research, Thousand Oaks: Sage Publications.

Haji, E. EL., Azmani, A., and Harzli, M.EL. (2014). Multi-expert system design for educational and career guidance: an approach based on a multi-agent system and ontology, International J ournal of Computer Science Issues, 11(5), 46-52

Hevner, A. and Chatterjee, S. (2010). Design Research In Information Systems: Theory And Practice, Springer Science \& Business Media.

Hevner, A. R., March, S. T., Park, J. and Ram, S. (2004). Design Science in Information Systems Research. Management Information Systems Quarterly, 28(1), 75-105.

Hevner, A.R. (2007). A Three Cycle View of Design Science Research, Scandinavian J ournal of Information Systems (19)2, 87- 92.

Hull, L.G. and Kay, P. (1991). Expert System Development Methodology and Management, Proceedings of the IEEE/ACM International Conference on Developing and Managing Expert System Programs, Washington, DC 
Hwang, G-J ., Chen, C-Y., Tsai, P-S., and Tsai, C-C. (2011). An expert system for improving webbased problem-solving ability of students, Expert Systems with Applications, 38 (7), 8664- 8672.

Indulska, M. and Recker, J. (2010). Design Science In Is Research: A Literature Analysis. Information Systems Foundations, 285.

Jaques, P. A., Seffrin, H., Rubi, G., Morais, F. D., Guilardi, C., Bittencourt, I. I. et al. (2013).Rule-based Expert Systems to support step-by-step guidance in Algebraic Problem Solving: the case of the Tutor PAT2Math. Expert Systems with Applications, 40 (14), 5456-5465

J ohnson, R. B., and Onwuegbuzie, A. J . (2004). Mixed methods research: A research paradigm whose time has come, Educational researcher, 33(7), 14-26.

Kaidar, S. M., Hussain, R. I., Bohani, F.A., Sahran, S., Zainuddin, N.B., Ismail, F., Thanabalan, J., Kalimuthu, G. and Abdullah, S.N. H. S. (2012). Brain tumor treatment advisory system. Soft Computing Applications and Intelligent Systems. Springer, UK

Khan, F. S., Razzaq, S., Irfan, K., Maqbool, F., Farid, A., Illahi, I. and Amin, T. U (2008). Wheat: A Web-based expert system for diagnosis of diseases and pests in Pakistani wheat, Proceedings of the World Congress on Engineering, 2-4.

Kim, I. and Kuljis, J . (2010). Applying content analysis to Web based content, Proceedings of the 32nd IEEE International Conference on Information Technology Interfaces (ITI), Cavtat/ Dubrovnik, 283 - 288.

Lawson, D. (2012). Computer-aided assessment in mathematics: Panacea or propaganda?, International J ournal of Innovation in Science and Mathematics Education (formerly CAL-laborate International), 9(1).

Livne, N. L., Livne, O. E., and Wight, C. A. (2015). Can automated scoring surpass hand grading of students' constructed responses and error patterns in mathematics, In Conole et al. (ed) Design for Teaching and Learning in a Networked World, Springer.

Mansiya, K., Alma, K.Z., Marzhan, M.T.M. and Kanat, N. (2014) The Methodology of Expert Systems. International J ournal of Computer Science and Network Security, 14 (2 ), 1462.

March, S.T. and Smith, G. (1995). Design and natural science research on information technology, Decision Support Systems 15(4), 251-266

Miah, S.J . Kerr, D. and von-Helens, L (2014). A collective artefact design of decision support systems: design science research perspective, Information Technology \&People, 27 (3), 259-279.

Miah, S.J., Kerr, D. and Gammack, J. (2009). A Methodology to allow Rural Extension Professionals to build Target specific expert systems for Australian Rural Business Operators, Expert Systems with Applications, 36 (1), 735-744

Myers, M. D. (1997). Qualitative Research In Information Systems. Management Information Systems Quarterly, 21, 241-242.

Nunamaker, J .F., Chen, M., and Purdin, T.D.M. (1991). Systems Development in Information Systems Research, J ournal of Management Information Systems, 7(3), 89-106.

Orlikowski W. J . and Iacono C. S. (2001). Desperately seeking the "TT" in IT research - a call to theorizing the IT artifact, Information Systems Research, 12 (2), 121-134

Palm, T. (2008). Performance assessment and authentic assessment: A conceptual analysis of the literature?, Practical Assessment, Research \&Evaluation, 13(4), 1-11. 
Price, M., Carroll, J ., O’Donovan, B., and Rust, C. (2011). If I was going there I wouldn't start from here: a critical commentary on current assessment practice, Assessment \& Evaluation in Higher Education, 36(4), 479-492.

Power D (2010). What are concerns about end-user DSS development? Available: http:// dssresources.com/ faq/index.php?action=artikel\&id=208

Sanders, D., Tan, Y.C., Rogers, I., and Tewkesbury, G.E. (2009). An Expert System for automatic design for assembly, Assembly Automation, 29 (4), 378 - 388

Sangwin, C. (2012). Computer Aided Assessment of Mathematics, Oxford University Press, UK.

Sangwin, C., Cazes, C., Lee, A., and Wong, K. L. (2010). Micro-level automatic assessment supported by digital technologies Mathematics Education and Technology-Rethinking the Terrain (pp. 227-250): Springer.

Sasikumar, M., Ramani, S., Raman, S. M., Anjaneyulu, K., and Chandrasekar, R. (2007). A Practical Introduction to Rule Based Expert Systems, Narosa Publishers, India.

Shao, X Y, Chu, X.Z, Qiu, H.B., Gao, L. and Yan, J . (2009). An expert system using rough sets theory for aided conceptual design of ship's engine room automation, Expert Systems with Applications, 36 (2), 3223- 3233

Shiau, W.L. (2011). A profile of information systems research published in expert systems with applications from 1995 to 2008, Expert Systems with Applications 38, 3999- 4005

Simon, H. A. (1996). The Sciences of the Artificial (3rd ed.), MIT Press, Cambridge, MA.

Stalnaker, R. (2012). Intellectualism and the objects of knowledge. Philosophy and Phenomenological Research, 85(3), 754-761

Turban, E., Aronson, J. and Liang, T.-P. (2005). Decision Support Systems And Intelligent Systems 7th Edition, Pearson Prentice Hall.

Vaishnavi, V. K. and Kuechler, W. (2015). Design Science Research Methods And Patterns: Innovating Information And Communication Technology, CRC Press.

Walls J .G., Widmeyer, G.R and EL Sawy, O.A. (1992) Building an information system design theory for vigilant EIS. Information Systems Research 3(1), 36-59.

Walls, J.G, Widmeyer,G.R. and EL sawy, O.A. (2004). Assessing information system design theory in perspective: how useful was our 1992 initial rendition?. J ournal of Information Technology Theory and Application 6 (2), 43-58.

Waterman, D. A. (1986). A guide to expert systems: Reading, Mass. Addison-Wesley, UK.

Wiliam, D. (2005). Keeping learning on track: Formative assessment and the regulation of learning. Making mathematics vital, 20-34.

Wu,P-H., Hwang, G-J ., Su, L-H., and Huang, Y-M. (2012). A Context-Aware Mobile Learning System for Supporting Cognitive Apprenticeships in Nursing Skills Training, J ournal of Educational Technology \& Society, 15 (1), 223-236. 


\section{Appendix A: Table A1: Analysis of the 20 sample ES articles}

\begin{tabular}{|c|c|c|c|c|c|c|c|}
\hline 象 & $\begin{array}{l}\text { Artefacts } \\
\text { (model, } \\
\text { methods, } \\
\text { constructs and } \\
\text { instantiations) }\end{array}$ & $\begin{array}{l}\text { Problem } \\
\text { relevance }\end{array}$ & $\begin{array}{l}\text { Evaluation } \\
\text { of design }\end{array}$ & Contribution & Rigour & Design as search process & $\begin{array}{l}\text { Communication of } \\
\text { research }\end{array}$ \\
\hline 1 & Instantiations & $\begin{array}{l}\text { Engine room } \\
\text { design }\end{array}$ & Case study & $\begin{array}{l}\text { Rapid intelligent } \\
\text { design solution }\end{array}$ & $\begin{array}{l}\text { Rigour applied } \\
\text { at all of the } \\
\text { design phases }\end{array}$ & $\begin{array}{l}\text { Designer achieved desired } \\
\text { problem specific goals, } \\
\text { optimal design }\end{array}$ & $\begin{array}{l}\text { To both industry and } \\
\text { academic audience }\end{array}$ \\
\hline 2 & Instantiations & Clinical health & $\begin{array}{l}\text { Performance } \\
\text { evaluations } \\
\text { with } \\
\text { measures of } \\
\text { specificity, } \\
\text { sensitivity } \\
\text { and } \\
\text { accuracy. } \\
\text { used } \\
\text { descriptive } \\
\text { approach }\end{array}$ & $\begin{array}{l}\text { Solution } \\
\text { development }\end{array}$ & $\begin{array}{l}\text { Rigour is } \\
\text { applied at } \\
\text { multiple phases } \\
\text { of interviews to } \\
\text { ensure quality } \\
\text { and used } \\
\text { questioners }\end{array}$ & $\begin{array}{l}\text { Enough relevant patient data } \\
\text { were collected as KB } \\
\text { components and literature in } \\
\text { the relevant areas was } \\
\text { reviewed and verified. For } \\
\text { knowledge representation } \\
\text { fuzzy production rules and } \\
\text { inference engine } \\
\text { implemented diagnostic rules } \\
\text { and organising rules using } \\
\text { concepts of modules and } \\
\text { used meta-rules and rule } \\
\text { checking techniques }\end{array}$ & $\begin{array}{l}\text { The system is } \\
\text { communicated to } \\
\text { industry stakeholders } \\
\text { and academics by } \\
\text { publication for } \\
\text { academic audience }\end{array}$ \\
\hline 3 & Instantiations & $\begin{array}{l}\text { Fault } \\
\text { diagnosis of } \\
\text { dredgers }\end{array}$ & $\begin{array}{l}\text { Performance } \\
\text { testing; used } \\
\text { experimental } \\
\text { approach }\end{array}$ & $\begin{array}{l}\text { Solution design } \\
\text { for fault } \\
\text { diagnosing and } \\
\text { prevention }\end{array}$ & $\begin{array}{l}\text { Interviews and } \\
\text { field } \\
\text { experiences and } \\
\text { actual operation } \\
\text { of dredgers. } \\
\text { Publications } \\
\text { and technical } \\
\text { documents were } \\
\text { used }\end{array}$ & $\begin{array}{l}\text { The ES was made up with } \\
\text { neural networks and hybrid } \\
\text { knowledge to ensure } \\
\text { appropriate diagnosis }\end{array}$ & Academic audience \\
\hline
\end{tabular}




\begin{tabular}{|c|c|c|c|c|c|c|c|}
\hline 4 & Instantiations & $\begin{array}{l}\text { Support } \\
\text { learning } \\
\text { activity }\end{array}$ & $\begin{array}{l}\text { Assessed } \\
\text { how the } \\
\text { content was } \\
\text { developed } \\
\text { through the } \\
\text { use of } \\
\text { experimental } \\
\text { approach }\end{array}$ & $\begin{array}{l}\text { Interactive ES } \\
\text { development to } \\
\text { achieve the } \\
\text { learning goals } \\
\text { through } \\
\text { education } \\
\text { objectives }\end{array}$ & $\begin{array}{l}\text { The repertory } \\
\text { gird by teaching } \\
\text { and students to } \\
\text { ensure the } \\
\text { accuracy of the } \\
\text { knowledge. The } \\
\text { rigour for } \\
\text { evaluation is }\end{array}$ & $\begin{array}{l}\text { The knowledge is } \\
\text { represented by repertory grid } \\
\text { for a problem domain }\end{array}$ & $\begin{array}{l}\text { Experimented results } \\
\text { are presented to } \\
\text { participants and } \\
\text { academics community } \\
\text { by publication }\end{array}$ \\
\hline 5 & Instantiations & $\begin{array}{l}\text { Quantitative } \\
\text { research }\end{array}$ & $\begin{array}{l}\text { User } \\
\text { satisfaction } \\
\text { through the } \\
\text { use of } \\
\text { experimental } \\
\text { and case } \\
\text { study } \\
\text { approaches }\end{array}$ & $\begin{array}{l}\text { ES provides help } \\
\text { them to analyse } \\
\text { research } \\
\text { questionnaires. }\end{array}$ & $\begin{array}{l}\text { Rigour was } \\
\text { ensured during } \\
\text { the evaluation } \\
\text { and artefact } \\
\text { design process } \\
\text { through }\end{array}$ & $\begin{array}{l}\text { ES developed a knowledge } \\
\text { base from the experience of } \\
\text { senior researchers } \\
\text { design process incorporate } \\
\text { object oriented approach into } \\
\text { ES, the knowledge comes } \\
\text { from interview of expert of } \\
\text { the data analysis to construct } \\
\text { ontology }\end{array}$ & $\begin{array}{l}\text { Experimented results } \\
\text { are presented to senior } \\
\text { and junior researchers } \\
\text { and academic } \\
\text { community by } \\
\text { publication }\end{array}$ \\
\hline 6 & Instantiations & $\begin{array}{l}\text { Chinese } \\
\text { medicine }\end{array}$ & $\begin{array}{l}\text { Evaluation } \\
\text { was done in } \\
\text { terms of } \\
\text { Verifications } \\
\text { \&Validations } \\
\text { using } \\
\text { redundancy, } \\
\text { circularity } \\
\text { and } \\
\text { incompletene } \\
\text { ss rules }\end{array}$ & $\begin{array}{l}\text { Provided tool } \\
\text { for physician, } \\
\text { family doctor } \\
\text { and medical } \\
\text { student for } \\
\text { knowledge } \\
\text { management }\end{array}$ & $\begin{array}{l}\text { Rigour was } \\
\text { ensured } \\
\text { through } \\
\text { phenomenon } \\
\text { study using } \\
\text { behavioural } \\
\text { sciences } \\
\text { Reviewers } \\
\text { commented on } \\
\text { the findings of } \\
\text { the issues and } \\
\text { application of } \\
\text { patients } \\
\text { evaluation }\end{array}$ & $\begin{array}{l}\text { Used ontology for knowledge } \\
\text { base of the ES, followed } \\
\text { knowledge extracted from } \\
\text { expert (interviews) in the } \\
\text { field of Chinese medicine and } \\
\text { also applied object oriented } \\
\text { technique and security } \\
\text { technique for data }\end{array}$ & $\begin{array}{l}\text { Research findings were } \\
\text { presented to students for } \\
\text { educational purpose and } \\
\text { academics by } \\
\text { publication }\end{array}$ \\
\hline 7 & Instantiations & $\begin{array}{l}\text { Constructions } \\
\text { (engineering) } \\
\text { issues }\end{array}$ & $\begin{array}{l}\text { Multiple } \\
\text { evaluation } \\
\text { methods } \\
\text { (field testing, } \\
\text { unit testing, } \\
\text { satisfaction } \\
\text { testing, }\end{array}$ & $\begin{array}{l}\text { Developing ES } \\
\text { for providing } \\
\text { construction } \\
\text { knowledge in } \\
\text { may conditions } \\
\text { for engineers } \\
\text { and transferring }\end{array}$ & $\begin{array}{l}\text { Rigour is } \\
\text { applied in } \\
\text { collecting data } \\
\text { the behavioural } \\
\text { science } \\
\text { knowledge are } \\
\text { used. Reviewing }\end{array}$ & $\begin{array}{l}\text { Conducted literature review } \\
\text { and observation to collect } \\
\text { knowledge, analysing } \\
\text { collected knowledge using } \\
\text { iterative search process }\end{array}$ & Academic audience \\
\hline
\end{tabular}




\begin{tabular}{|c|c|c|c|c|c|c|c|}
\hline & & & $\begin{array}{l}\text { integration } \\
\text { testing) were } \\
\text { used for } \\
\text { Verifications } \\
\& \\
\text { Validations. } \\
\text { Using } \\
\text { optimisation } \\
\text { model to } \\
\text { evaluate the } \\
\text { efficiency of } \\
\text { ES }\end{array}$ & $\begin{array}{l}\text { knowledge from } \\
\text { engineers to } \\
\text { engineers }\end{array}$ & $\begin{array}{l}\text { collected } \\
\text { knowledge and } \\
\text { content analysis }\end{array}$ & & \\
\hline 8 & Instantiations & $\begin{array}{l}\text { Electrical } \\
\text { control }\end{array}$ & $\begin{array}{l}\text { Experiment } \\
\text { method, The } \\
\text { evaluation } \\
\text { was } \\
\text { conducted } \\
\text { using } \\
\text { representativ } \\
\text { e seven } \\
\text { problem } \\
\text { cases }\end{array}$ & $\begin{array}{l}\text { Improved co- } \\
\text { ordination } \\
\text { settings of } \\
\text { protection } \\
\text { devices } \\
\text { (generators) by } \\
\text { solving } \\
\text { complexity of } \\
\text { the co- } \\
\text { ordination } \\
\text { problem }\end{array}$ & $\begin{array}{l}\text { Systematically } \\
\text { designed and } \\
\text { evaluated the } \\
\text { ES and } \\
\text { knowledge } \\
\text { gathered from } \\
\text { relevant sources }\end{array}$ & $\begin{array}{l}\text { Sub-divisions of the ES } \\
\text { solution in four portions }\end{array}$ & Academic audience \\
\hline 9 & Instantiations & $\begin{array}{l}\text { Health- } \\
\text { diagnosing } \\
\text { asthma }\end{array}$ & $\begin{array}{l}\text { Practical } \\
\text { scenario } \\
\text { based testing } \\
\text { for the } \\
\text { verifications } \\
\& \text { validations }\end{array}$ & $\begin{array}{l}\text { Diagnosing } \\
\text { asthma at initial } \\
\text { stages }\end{array}$ & $\begin{array}{l}\text { For KA, they } \\
\text { used interview, } \\
\text { task } \\
\text { performance, } \\
\text { protocol and } \\
\text { text books, } \\
\text { domain experts } \\
\text { and users. They } \\
\text { used fuzzy } \\
\text { technology and } \\
\text { semantic } \\
\text { network to } \\
\text { representation } \\
\text { of knowledge }\end{array}$ & $\begin{array}{l}\text { Used life-cycle based } \\
\text { methodology, taking } \\
\text { participatory design process. } \\
\text { The performance of the } \\
\text { system }\end{array}$ & $\begin{array}{l}\text { Published in journal and } \\
\text { communicated to the } \\
\text { target stakeholders }\end{array}$ \\
\hline
\end{tabular}




\begin{tabular}{|c|c|c|c|c|c|c|c|}
\hline 10 & Instantiations & $\begin{array}{l}\text { Selecting } \\
\text { Information } \\
\text { Systems } \\
\text { Development } \\
\text { Methodologies }\end{array}$ & $\begin{array}{l}\text { The ES was } \\
\text { evaluated } \\
\text { through face } \\
\text { validation, } \\
\text { predictive } \\
\text { validation } \\
\text { and blind } \\
\text { validation }\end{array}$ & $\begin{array}{l}\text { Automated the } \\
\text { process of } \\
\text { section of } \\
\text { appropriate } \\
\text { Systems } \\
\text { Development } \\
\text { Methodologies }\end{array}$ & $\begin{array}{l}\text { Used standard } \\
\text { ES development } \\
\text { phases }\end{array}$ & $\begin{array}{l}\text { There are phases such as } \\
\text { phase 1: identification phase, } \\
\text { phase 2: determination } \\
\text { phase, phase 3: selection } \\
\text { phase, and the phase } 4: \\
\text { expert system development } \\
\text { phase. }\end{array}$ & $\begin{array}{l}\text { Published in journal and } \\
\text { communicated to the } \\
\text { target stakeholders and } \\
\text { academic audience }\end{array}$ \\
\hline 11 & Model & $\begin{array}{l}\text { Student } \\
\text { consulting } \\
\text { system }\end{array}$ & None & $\begin{array}{l}\text { Web-based } \\
\text { student } \\
\text { consulting ES } \\
\text { for the } \\
\text { educational } \\
\text { advisers to } \\
\text { solve student's } \\
\text { rules and } \\
\text { regulations } \\
\text { related issues }\end{array}$ & $\begin{array}{l}\text { Rigour was } \\
\text { applied through } \\
\text { the } \\
\text { methodology } \\
\text { comprised with } \\
\text { specific } \\
\text { activities such } \\
\text { as fizzification } \\
\text { of the crisp } \\
\text { variable, rule } \\
\text { extraction, data } \\
\text { centralisation, } \\
\text { putting info on } \\
\text { web, } \\
\text { considering the } \\
\text { exclusion issue } \\
\text { of a student, } \\
\text { look inside the } \\
\text { system, } \\
\text { implementation } \\
\text { environment }\end{array}$ & $\begin{array}{l}\text { Used fuzzy logic technique to } \\
\text { design the ES }\end{array}$ & Academic audience \\
\hline 12 & Instantiations & $\begin{array}{l}\text { Housing } \\
\text { construction } \\
\text { and design }\end{array}$ & $\begin{array}{l}\text { User } \\
\text { satisfaction } \\
\text { testing } \\
\text { through } \\
\text { iterative } \\
\text { methodology }\end{array}$ & $\begin{array}{l}\text { Provided } \\
\text { comprehensive } \\
\text { understanding } \\
\text { of daylighting } \\
\text { and offers user } \\
\text { interactivity } \\
\text { regarding design } \\
\text { choices }\end{array}$ & $\begin{array}{l}\text { Rigour was } \\
\text { applied through } \\
\text { iterative } \\
\text { method in the } \\
\text { design and } \\
\text { evaluation } \\
\text { phases }\end{array}$ & $\begin{array}{l}\text { For KA the ES used a } \\
\text { daylighting database which } \\
\text { contains information } \\
\text { regarding the effects of a } \\
\text { variety of design conditions } \\
\text { on resultant daylighting } \\
\text { performance and controlled } \\
\text { by a fuzzy rule based decision } \\
\text { making logic that is used to } \\
\text { determine those design }\end{array}$ & $\begin{array}{l}\text { Communicated to } \\
\text { participants and } \\
\text { academic audience }\end{array}$ \\
\hline
\end{tabular}




\begin{tabular}{|c|c|c|c|c|c|c|c|}
\hline & & & & & & $\begin{array}{l}\text { changes most likely to } \\
\text { improve performance for a } \\
\text { given design }\end{array}$ & \\
\hline 13 & Instantiations & $\begin{array}{l}\text { Design in } \\
\text { product } \\
\text { manufacturing }\end{array}$ & $\begin{array}{l}\text { The ES is } \\
\text { evaluated } \\
\text { through test } \\
\text { cases using } \\
\text { real product } \\
\text { data }\end{array}$ & $\begin{array}{l}\text { Provided } \\
\text { designers } \\
\text { suggestions for } \\
\text { changing the } \\
\text { design (design } \\
\text { for assembly } \\
\text { automation) at } \\
\text { early stage }\end{array}$ & $\begin{array}{l}\text { Rigour was } \\
\text { applied in } \\
\text { making sure } \\
\text { that effective } \\
\text { knowledge } \\
\text { acquired for } \\
\text { storing rules } \\
\text { and facts about } \\
\text { the particular } \\
\text { knowledge } \\
\text { domain }\end{array}$ & $\begin{array}{l}\text { The ES was designed through } \\
\text { steps such as The steps } \\
\text { involved creating: CAD } \\
\text { expert to interpret CDA } \\
\text { drawing files and extract } \\
\text { assembly data, User } \\
\text { interface, Automated } \\
\text { assembly expert, Human } \\
\text { assembly expert, and design } \\
\text { analysis expert }\end{array}$ & $\begin{array}{l}\text { Communicated to target } \\
\text { users and academic } \\
\text { audience }\end{array}$ \\
\hline 14 & Model & $\begin{array}{l}\text { Education and } \\
\text { career } \\
\text { development }\end{array}$ & None & $\begin{array}{l}\text { ES designed for } \\
\text { providing } \\
\text { educational and } \\
\text { career guidance } \\
\text { by envisaging } \\
\text { four areas of } \\
\text { expertise and } \\
\text { thus four } \\
\text { experts: } \\
\text { pedagogical } \\
\text { expert, } \\
\text { psychological } \\
\text { expert and } \\
\text { sociological } \\
\text { expert and } \\
\text { economic expert }\end{array}$ & $\begin{array}{l}\text { Rigour was } \\
\text { applied in } \\
\text { demonstrating } \\
\text { the design } \\
\text { process } \\
\text { concepts. }\end{array}$ & $\begin{array}{l}\text { Used a multi-agent approach } \\
\text { and the semantic web in } \\
\text { developing the solution } \\
\text { To enable communication } \\
\text { and collaboration between } \\
\text { the agents were the key } \\
\text { requirements that are } \\
\text { identified in the paper. } \\
\text { Simply applied a project } \\
\text { management } \\
\text { approach/ software } \\
\text { engineering (indirectly). The } \\
\text { paper is focused on } \\
\text { describing the technical } \\
\text { architecture of their ES }\end{array}$ & Academic audience \\
\hline 15 & Model & $\begin{array}{l}\text { Management } \\
\text { of academics } \\
\text { by the head of } \\
\text { Department } \\
\text { in university }\end{array}$ & None & $\begin{array}{l}\text { ES designed for } \\
\text { providing } \\
\text { assistance to the } \\
\text { head of } \\
\text { Department in } \\
\text { Universities for } \\
\text { assisting in } \\
\text { employing }\end{array}$ & $\begin{array}{l}\text { Rigour was } \\
\text { applied by } \\
\text { following design } \\
\text { steps such as for } \\
\text { rules in } \\
\text { developing } \\
\text { decision trees } \\
\text { on the facts }\end{array}$ & $\begin{array}{l}\text { Conducted a systematic study } \\
\text { by interviewing heads of } \\
\text { three different departments } \\
\text { in order to identify } 30 \\
\text { different instances of } \\
\text { decision making }\end{array}$ & Academic audience \\
\hline
\end{tabular}




\begin{tabular}{|c|c|c|c|c|c|c|c|}
\hline & & & & $\begin{array}{l}\text { lecturers based } \\
\text { on some default } \\
\text { factors }\end{array}$ & $\begin{array}{l}\text { which extracted } \\
\text { of human } \\
\text { expert } \\
\text { knowledge }\end{array}$ & & \\
\hline 16 & Instantiations & Art and design & $\begin{array}{l}\text { A case study } \\
\text { based } \\
\text { evaluation } \\
\text { was } \\
\text { conducted }\end{array}$ & $\begin{array}{l}\text { Analysis and } \\
\text { interpretation of } \\
\text { drawing art } \\
\text { therapy tools }\end{array}$ & $\begin{array}{l}\text { Rigour was } \\
\text { applied through } \\
\text { design and } \\
\text { evaluation } \\
\text { process }\end{array}$ & $\begin{array}{l}\text { Conduced systematic design } \\
\text { process using existing } \\
\text { theories and practice based } \\
\text { knowledge and expert } \\
\text { knowledge in art therapy }\end{array}$ & $\begin{array}{l}\text { Communicating about } \\
\text { the ES to domain experts } \\
\text { and published in journal }\end{array}$ \\
\hline 17 & Instantiations & $\begin{array}{l}\text { Operation of } \\
\text { competency } \\
\text { management }\end{array}$ & $\begin{array}{l}\text { Evaluation } \\
\text { was } \\
\text { conducted } \\
\text { through the } \\
\text { verification } \\
\text { and } \\
\text { validations } \\
\text { using case } \\
\text { study } \\
\text { (evaluating } \\
\text { performance } \\
\text { of the } \\
\text { system, } \\
\text { effectiveness } \\
\text { and } \\
\text { accuracy) }\end{array}$ & $\begin{array}{l}\text { Provided } \\
\text { support to } \\
\text { enhance the } \\
\text { management of } \\
\text { competence }\end{array}$ & $\begin{array}{l}\text { Rigour was } \\
\text { applied through } \\
\text { adopting design } \\
\text { and } \\
\text { development } \\
\text { phases of ES } \\
\text { (task analysis, } \\
\text { knowledge } \\
\text { acquisition, } \\
\text { prototype } \\
\text { development, } \\
\text { expansion and } \\
\text { refinement and } \\
\text { verification and } \\
\text { validations) }\end{array}$ & $\begin{array}{l}\text { Knowledge acquired through } \\
\text { interviewing of the field } \\
\text { experts (competency } \\
\text { managers) }\end{array}$ & $\begin{array}{l}\text { Communicating about } \\
\text { the stakeholders and } \\
\text { published in journal for } \\
\text { Academic audience }\end{array}$ \\
\hline 18 & Method & $\begin{array}{l}\text { Online } \\
\text { consumer } \\
\text { satisfaction }\end{array}$ & $\begin{array}{l}\text { Experiment } \\
\text { method, for } \\
\text { validity } \\
\text { testing }\end{array}$ & $\begin{array}{l}\text { ES designed for } \\
\text { detecting } \\
\text { Online } \\
\text { consumer } \\
\text { satisfaction by } \\
\text { providing } \\
\text { predictive } \\
\text { results } \\
\text { Incorporated } \\
\text { data mining } \\
\text { system with ES } \\
\text { using a Bayesian } \\
\text { fusion } \\
\text { framework }\end{array}$ & $\begin{array}{l}\text { Rigour was } \\
\text { applied through } \\
\text { a case study }\end{array}$ & $\begin{array}{l}\text { Conducted a systematic } \\
\text { design process that consists } \\
\text { of data collection, data } \\
\text { preparation and data } \\
\text { analysis. }\end{array}$ & Academic audience \\
\hline
\end{tabular}




\begin{tabular}{|l|l|l|l|l|l|l|}
\hline 19 & Instantiations & $\begin{array}{l}\text { Feedback } \\
\text { reviews and } \\
\text { bidding in } \\
\text { online } \\
\text { auctions }\end{array}$ & $\begin{array}{l}\text { Experiment } \\
\text { method, for } \\
\text { testing } \\
\text { accuracy of } \\
\text { prediction }\end{array}$ & $\begin{array}{l}\text { ES designed for } \\
\text { examining } \\
\text { feedback and } \\
\text { bidding of } \\
\text { online auctions }\end{array}$ & $\begin{array}{l}\text { Rigour was } \\
\text { applied through } \\
\text { a systematic } \\
\text { data collection } \\
\text { and model } \\
\text { design phases }\end{array}$ & $\begin{array}{l}\text { The ES used integrated } \\
\text { approach of fuzzy logic } \\
\text { expert system model and a } \\
\text { statistical hedonic regression } \\
\text { model }\end{array}$ \\
\hline 20 & Method & Healthcare & $\begin{array}{l}\text { Experiment } \\
\text { method }\end{array}$ & $\begin{array}{l}\text { ES designed for } \\
\text { detecting } \\
\text { consumer } \\
\text { satisfaction }\end{array}$ & $\begin{array}{l}\text { Rigour was } \\
\text { applied through } \\
\text { systematic } \\
\text { analysis }\end{array}$ & $\begin{array}{l}\text { Conducted a systematic } \\
\text { design process that consists } \\
\text { of data collection and design } \\
\text { solution development }\end{array}$ \\
\hline
\end{tabular}

Copyright: (c) 2016 Miah \& Genemo. This is an open-access article distributed under the terms of the Creative Commons AttributionNonCommercial 3.0 Australia License, which permits non-commercial use, distribution, and reproduction in any medium, provided the original author and AJ IS are credited. 